\title{
Chemical characterization of atmospheric ions at the high altitude research station Jungfraujoch (Switzerland)
}

\author{
Carla Frege $^{1}$, Federico Bianchi ${ }^{1,2}$, Ugo Molteni ${ }^{1}$, Jasmin Tröstl ${ }^{1}$, Heikki Junninen ${ }^{2}$, Stephan Henne ${ }^{3}$, Mikko Sipilä ${ }^{2}$, \\ Erik Herrmann $^{1}$, Michel J. Rossi ${ }^{1}$, Markku Kulmala ${ }^{2}$, Christopher R. Hoyle ${ }^{1,4}$, Urs Baltensperger ${ }^{1}$, and \\ Josef Dommen ${ }^{1}$ \\ ${ }^{1}$ Laboratory of Atmospheric Chemistry, Paul Scherrer Institute, 5232 Villigen, Switzerland \\ ${ }^{2}$ Department of Physics, University of Helsinki, 00014 Helsinki, Finland \\ ${ }^{3}$ Laboratory for Air Pollution/Environmental Technology, Swiss Federal Laboratories for Materials Science and Technology, \\ Empa, 8600 Dübendorf, Switzerland \\ ${ }^{4}$ WSL (Swiss Federal Institute for Forest, Snow and Landscape Research) Institute for Snow and Avalanche Research SLF, \\ 7260 Davos, Switzerland
}

Correspondence to: Josef Dommen (josef.dommen@psi.ch)

Received: 7 August 2016 - Discussion started: 7 September 2016

Revised: 1 December 2016 - Accepted: 20 December 2016 - Published: 21 February 2017

\begin{abstract}
The ion composition at high altitude (3454 ma.s.1.) was measured with an atmospheric pressure interface time-of-flight mass spectrometer (APi-TOF) during a period of 9 months, from August 2013 to April 2014. The negative mass spectra were dominated by the ions of sulfuric, nitric, malonic, and methanesulfonic acid (MSA) as well as $\mathrm{SO}_{5}^{-}$. The most prominent positive ion peaks were from amines. The other cations were mainly organic compounds clustered with a nitrogen-containing ion, which could be either $\mathrm{NH}_{4}^{+}$or an aminium. Occasionally the positive spectra were characterized by groups of compounds each differing by a methylene group. In the negative spectrum, sulfuric acid was always observed during clear sky conditions following the diurnal cycle of solar irradiation. On many occasions we also saw a high signal of sulfuric acid during nighttime when clusters up to the tetramer were observed. A plausible reason for these events could be evaporation from particles at low relative humidity. A remarkably strong correlation between the signals of $\mathrm{SO}_{5}^{-}$ and $\mathrm{CH}_{3} \mathrm{SO}_{3}^{-}$was observed for the full measurement period. The presence of these two ions during both the day and the night suggests a non-photochemical channel of formation which is possibly linked to halogen chemistry. Halogenated species, especially $\mathrm{Br}^{-}$and $\mathrm{IO}_{3}^{-}$, were frequently observed in air masses that originated mainly from the Atlantic Ocean and occasionally from continental areas based on
\end{abstract}

back trajectory analyses. We found $\mathrm{I}_{2} \mathrm{O}_{5}$ clustered with an ion, a species that was proposed from laboratory and modeling studies. All halogenated ions exhibited an unexpected diurnal behavior with low values during daytime. New particle formation (NPF) events were observed and characterized by (1) highly oxygenated molecules (HOMs) and low sulfuric acid or (2) ammonia-sulfuric acid clusters. We present characteristic spectra for each of these two event types based on 26 nucleation episodes. The mass spectrum of the ammonia-sulfuric acid nucleation event compares very well with laboratory measurements reported from the CLOUD chamber. A source receptor analysis indicates that NPF events at the Jungfraujoch take place within a restricted period of time of 24-48 h after air masses have had contact with the boundary layer. This time frame appears to be crucial to reach an optimal oxidation state and concentration of organic molecules necessary to facilitate nucleation.

\section{Introduction}

Understanding the occurrence and composition of ions in the atmosphere is important because they regulate the electrical properties of the atmospheric medium, participate in ion-catalyzed and ion-molecule reactions, and contribute to physicochemical interactions, including ion-induced new 
particle formation (NPF) (Schulte and Arnold, 1990). Ionization in the atmosphere takes place via different routes depending on the altitude. In the lower troposphere, ions are produced by radioactive emanation (mainly radon decay and gamma radiation), lightning, and galactic cosmic rays (GCR), resulting in a production rate of about 2 ionpairs $\mathrm{cm}^{-3} \mathrm{~s}^{-1}$ at sea level. This production rate increases with altitude, mainly due to increasing GCR intensity, reaching maximum rates of $35-50$ ion-pairs $\mathrm{cm}^{-3} \mathrm{~s}^{-1}$ at $15 \mathrm{~km}$ (Arnold, 2008; Hirsikko et al., 2011; Smith and Spanel, 1996). The first observations of ions in the free troposphere and stratosphere were reported by Heitmann and Arnold (1983). By using ion mass spectrometers at high altitude (either on aircraft, balloons, or rockets), they found that the main ions in the free troposphere were complex cluster ions containing $\mathrm{H}_{2} \mathrm{SO}_{4}, \mathrm{H}_{2} \mathrm{O}, \mathrm{HNO}_{3},\left(\mathrm{CH}_{3}\right)_{2} \mathrm{CO}$, and $\mathrm{CH}_{3} \mathrm{CN}$. In the last decade, the interest in atmospheric ions increased because of the potential impact of ion-aerosolcloud interactions on climate (Hirsikko et al., 2011; Kirkby, 2007; Kirkby et al., 2011, 2016). Therefore, a number of laboratory and field studies have been conducted aimed at increasing our understanding of the precise role of ions in new particle formation. High altitude sites, which are often located in the free troposphere, represent an interesting region with a low condensational sink and low temperatures, i.e., conditions that facilitate the formation of new particles. In addition, the higher concentration of ions at high altitudes could enhance ion-induced new particle formation. Although several studies have reported on ions in the free troposphere and their link with new particle formation (Boulon et al., 2010; Rose et al., 2015; Venzac et al., 2008), they only presented the total ion concentrations but no chemical composition.

The low concentration of ions in the atmosphere has proven to be an obstacle in determining their chemical composition. Recent improvements in mass spectrometer detection limits now enables the measurement of the composition of ions and ion clusters at atmospheric concentrations and pressure using the atmospheric pressure interface time-offlight mass spectrometer (APi-TOF) (Junninen et al., 2010). First atmospheric measurements with the APi-TOF were reported by Junninen et al. (2010) and Ehn et al. (2010), both for the boreal forest site Hyytiälä, in southern Finland. To our knowledge, no studies have yet been carried out to characterize the diurnal and seasonal trends and the chemical composition of air ions and ion clusters in the free troposphere. Here we present 9 months of continuous measurements at the high altitude research station Jungfraujoch (JFJ, Switzerland), located at $3454 \mathrm{~m}$ a.s.l. The measurements were part of the NUcleation, CLoud and Aerosol Characterization Experiment (NUCLACE) campaign and complement studies on detailed new particle formation mechanisms (Bianchi et al., 2016) and longer-term new particle formation statistics (Tröstl et al., 2016a). The aim of this work was to characterize the ion composition at this high altitude site and its possible link to source regions of the air masses and to new particle formation.

\section{Methods}

\subsection{Site description}

The high altitude research station JFJ, Switzerland (3454 ma.s.l.; $46.55^{\circ} \mathrm{N}, \quad 7.98^{\circ} \mathrm{E}$; http://hfsjg.ch) is often located in the free troposphere. The site is intermittently influenced by planetary boundary layer (PBL) air masses due to convective conditions and frontal systems varying from $80 \%$ of the time in summer to $60 \%$ in spring or autumn and $40 \%$ in winter (Henne et al., 2009; Herrmann et al., 2015; Zellweger et al., 2003). The JFJ is also a well-known tourist destination, which results in occasional contamination, for example by cigarette smoke (Fröhlich et al., 2015). This work shows results from a 9-month campaign of continuous measurements with a mass spectrometer from August 2013 to April 2014 (time is shown as local standard time (LST), UTC+1). Additionally, two intensive campaigns were conducted (January-March 2013 and January-March 2014) when many more instruments were employed for the study of NPF (see Bianchi et al., 2016).

\subsection{Instrumentation}

The main instrument in this study was an APi-TOF (Aerodyne Research Inc. and Tofwerk AG). The instrument is described in detail by Junninen et al. (2010). The APi-TOF operates in two stages. The first stage consists of a pressure interface where either the positive or the negative ions are focused and guided by two quadrupoles and an ion lens through three pumped chambers. Here the sampled flow is reduced from atmospheric pressure to $\sim 10^{-4}$ mbar. The second stage consists of a time-of-flight (TOF) mass spectrometer at a pressure of $10^{-6}$ mbar where ions are detected with a mass accuracy better than $5 \mathrm{ppm}$. The high sensitivity and resolution of the APi-TOF (resolving power around $5000 \mathrm{Th} \mathrm{Th}^{-1}$ ) helps to detect and identify atmospheric ions in spite of their low concentrations. Air was aspired through a stainless-steel tube of $1 \mathrm{~m}$ length and $25.4 \mathrm{~mm}$ inner diameter at $10 \mathrm{~L} \mathrm{~min}^{-1}$ of which $0.8 \mathrm{~L} \mathrm{~min}^{-1}$ entered the instrument.

The APi-TOF was set for high sensitivity detection in the mass-to-charge $(\mathrm{m} / \mathrm{z})$ range between 60 and $1200 \mathrm{Th}$ (short flight path in the TOF, V mode) and it was operated alternately between positive and negative mode, with $\sim 80 \%$ of the measurements conducted in negative mode. For the mentioned $\mathrm{m} / \mathrm{z}$ range it is assumed that the ions are within the detectable range of the APi-TOF and the relative change in signal of the individual ions corresponds to the absolute transmission. Data were analyzed using the software package tofTools, developed by the Department of Physics at the University of Helsinki. TofTools is implemented in MATLAB and allows the complete processing of the data, i.e., auto- 
matic averaging, mass calibration, baseline detection, peak deconvolution, and high-resolution analysis. The noise level is around $0.5 \times 10^{-3} \mathrm{~cm}^{-3}$ below $100 \mathrm{Th}$ and decreases to $0.1 \times 10^{-3} \mathrm{~cm}^{-3}$ at around 500 Th (Junninen et al., 2010). The assignment of the presented peaks was performed with an accuracy of $2 \mathrm{ppm}$ for the analysis of special cases and considering isotopic distribution. An example of the peak fitting is provided in Fig. S1 in the Supplement.

Initially the APi-TOF was installed at the Sphinx observatory at the JFJ ( $3580 \mathrm{~m}$ a.s.l.) on the upper platform where all the monitoring instrumentation is located, but no negative ions were measured due to electrostatic interaction with the building structure, mainly the cupula. Therefore the APiTOF was relocated at the JFJ research station (3454 m a.s.l.). Long-term observations at the Sphinx and the research station show no important difference in aerosol parameters (see Bukowiecki et al., 2016), and therefore our measurements should be comparable with those of the instruments at the Sphinx.

The JFJ is equipped with a suite of permanently operated atmospheric monitoring instrumentation (see Bukowiecki et al., 2016). In addition, a nano-scanning mobility particle sizer (nano-SMPS) was operated to determine the size distribution of freshly nucleated particles (Tröstl et al., 2016a). Meteorological data (relative humidity, temperature, wind direction, and global radiation) were obtained from the station operated at the JFJ by MeteoSwiss and were used at a time resolution of $10 \mathrm{~min}$.

\subsection{Transport simulation}

To study the origin of different air masses sampled at the JFJ, backward dispersion calculations were carried out with the Lagrangian particle dispersion model FLEXPART (LPDM, version 9.02; Stohl et al., 2005). FLEXPART calculates the trajectories of an ensemble of air parcels (called particles) through the atmosphere. The model considers transport by mean flow, turbulence, and subgrid convection. By simulating thousands of air parcels an LPDM can be used in a quantitative way to derive source receptor relationships (SRR), establishing the effect of an emission release from a source on the atmospheric concentration at a receptor. In a receptororiented approach, source sensitivities are derived from backward simulations, releasing air parcels at the location of the observation/receptor and following them backward in time. The derived SRRs provide information about when and where an air mass sampled at the receptor was in contact with the Earth's surface and potentially took up surface emissions.

Carbon monoxide emissions were also used as a tracer for anthropogenic activities and therefore PBL influence. Anthropogenic $\mathrm{CO}$ emissions were taken from the EDGARv4.2 emission inventory (http://edgar.jrc.ec.europa.eu/index. php) for the reference year 2008 (the latest available from the inventory).
Simulations were driven by 3-hourly operational analysis/forecast fields of the Integrated Forecasting System (IFS) of the European Centre for Medium Range Forecasts (ECMWF). The horizontal resolution of these inputs was $0.2^{\circ}$ by $0.2^{\circ}$ in the Alpine area and $1^{\circ}$ by $1^{\circ}$ elsewhere. For the JFJ simulations, 50000 model particles were released every $3 \mathrm{~h}$ and traced back in the atmosphere for 10 days. The model output in the form of near surface residence times (referred to as footprints or source sensitivities) was then used to analyze where sampled air masses had been exposed to surface fluxes (emissions).

\subsection{Determination of cloud coverage}

In order to distinguish between sunny and cloudy conditions, the cloud cover was estimated with the clear sky index (CSI) described by Marty and Philipona (2000). The CSI is defined as the ratio between the apparent emittance and the theoretical clear sky apparent emittance and is calculated from the atmospheric long-wave radiation, air temperature, and relative humidity. As the combination of these three parameters is available continuously, the presence of clouds at or above the JFJ can be determined during day and night. A CSI $\leq 1$ is considered as clear sky (no clouds), while a CSI $>1$ represents a cloudy sky (overcast). In addition, cloud coverage was also confirmed by comparing the CSI to pictures from cameras recording the panoramic view at the JFJ (http://panocam.skiline.cc/jungfraujoch and http://webcam.switch.ch/jungfraujoch/). These observations also help identify periods when the JFJ was in cloud.

\section{Results and discussion}

First we give an overview of the average composition of positive and negative ions at the JFJ. Thereafter, a few selected cases of special ion observations are presented. While this paper is strictly related to ions, for clarity we mention the ions with the name of the neutral molecule, e.g., sulfuric acid for $\mathrm{HSO}_{4}^{-}$and nitric acid for $\mathrm{NO}_{3}^{-}$.

For the full period of measurement we observed fluctuations in the total ion count (TIC). Fluctuations in the TIC were already noted by Boulon et al. (2010), who attributed this to the available ion precursors (e.g., radon) and the strength of the condensation sink. These fluctuations may also be due to the small mass range of ions measured with the APi-TOF; thus a change in the size distribution of the ions resulting in a different fraction of ions outside of the APi-TOF detection range could result in a TIC fluctuation. Still, this observation should not affect the qualitative analysis presented below.

\subsection{Main ion composition}

Negative ions were detected within an $m / z$ range of 601200 Th. Representative mass spectra for clear sky condi- 

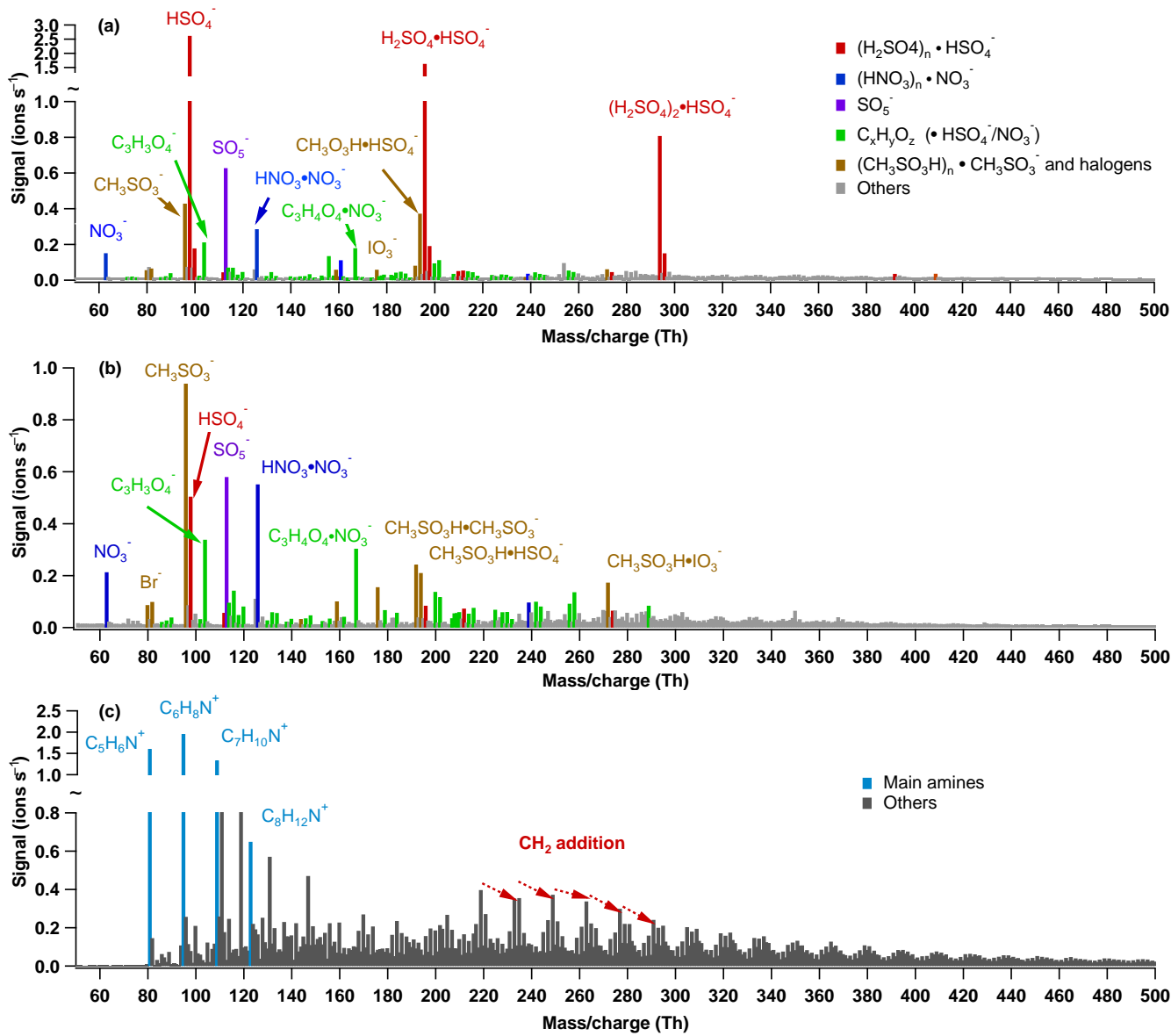

Figure 1. Representative mass spectra of ions from the Jungfraujoch. (a) Average daytime spectrum of negative ions from 53 cloudless days between 10:00 and 14:00 LST. (b) Average nighttime spectrum of negative ions from 22 cloudless nights between 22:00 and 02:00 LST. (c) Average spectrum of positive ions between 10:00 and 14:00 LST on 23 January 2013.

tions $(\mathrm{CSI} \leq 1)$ are given in Fig. 1. Figure 1a presents the average spectrum of 53 clear sky days during daytime (between 10:00 and 14:00 LST), showing sulfuric acid and its clusters (dimer, trimer) as the main ions. Other important ions are $\mathrm{SO}_{5}^{-}$, as well as the ions of nitric acid, methanesulfonic acid (MSA), and $\mathrm{C}_{3} \mathrm{H}_{3} \mathrm{O}_{4}^{-}$(most probably malonic acid). Figure $1 \mathrm{~b}$ shows the average spectrum of 22 clear sky nights (between 22:00 and 02:00 LST). In this case, sulfuric acid and its clusters were strongly reduced (although they are not completely absent), and the largest signal is from $\mathrm{CH}_{3} \mathrm{SO}_{3}^{-}$followed by $\mathrm{SO}_{5}^{-}$, nitric acid, and malonic acid (including their clusters). During both the day and the night, we observed the presence of organics, identified as $\mathrm{C}_{2-18} \mathrm{H}_{1-22} \mathrm{O}_{2-13}$, generally with high oxygen content. In the mass range $120-440 \mathrm{Th}$, organics occurred mainly in clusters with $\mathrm{NO}_{3}^{-}$or $\mathrm{HSO}_{4}^{-}$. Halogenated ions were found as well. Ions from iodine were mainly observed as $\mathrm{IO}_{3}^{-}$and in clusters with either $\mathrm{H}_{2} \mathrm{SO}_{4}$ or MSA, while ions from bromine were detected only as $\mathrm{Br}^{-}$. These ions were present during day and night, although their signal was highest dur- ing sunrise and sunset. No significant seasonal variation was observed in the composition of the main ions as shown in Fig. S2.

Positive ions were identified in the $\mathrm{m} / \mathrm{z}$ range of 70-300 Th. At low $\mathrm{m} / \mathrm{z}$ most of the peaks were identified as protonated amines and oxygenated organics $\left(\mathrm{C}_{3-14} \mathrm{H}_{5-18} \mathrm{O}_{1-6} \mathrm{H}^{+}\right)$. At high $\mathrm{m} / z(>120 \mathrm{Th})$ we found mostly $\mathrm{N}$-containing ions that could not be unambiguously attributed to amines or oxygenated organics clustered with a nitrogen-containing ion (either an ammonium or an aminium). In general, the positive spectrum contained less oxygenated organics compared to the negative mode spectrum, with no significant significant difference in composition between day and night. Schulte and Arnold (1990) reported that the main cation in the middle troposphere (3000-6000 m a.s.l.) was pyridine $\left(\mathrm{C}_{5} \mathrm{H}_{6} \mathrm{~N}^{+}\right)$. We also measured this as one of the main cations together with aniline $\left(\mathrm{C}_{6} \mathrm{H}_{8} \mathrm{~N}^{+}\right)$and benzylamine $\left(\mathrm{C}_{7} \mathrm{H}_{10} \mathrm{~N}^{+}\right)$. We do not present an average spectrum of the positive mode since we do not have sufficient data of clear sky days to generate an unbiased 
average spectrum. Occasionally, a sequence of peaks with an increasing number of methylene groups was observed as a clear pattern in the positive spectrum, mostly after a direct PBL contact (based on Herrmann et al., 2015); one example during 23 January 2013 is shown in Fig. 1c. Mostly during summer, some high intensity peaks, mainly at 163.1230 and 192.1383 Th, appeared, with the first one being potentially identified as nicotine $\left(\mathrm{C}_{10} \mathrm{H}_{15} \mathrm{~N}_{2}^{+}\right)$. The presence of these ions is most likely related to tourists smoking on the terrace of the JFJ station (Fröhlich et al., 2015).

Figure 2 shows the diurnal variations of the main negative ions normalized to the total negative ion count, averaged for 15 clear sky days (cloudless during the whole day). The figure classifies the ion counts into seven groups: sulfuric acid $\left(\mathrm{HSO}_{4}^{-}, \mathrm{H}_{2} \mathrm{SO}_{4} \cdot \mathrm{HSO}_{4}^{-}\right.$, and $\left.\left(\mathrm{H}_{2} \mathrm{SO}_{4}\right)_{2} \cdot \mathrm{HSO}_{4}^{-}\right)$, nitric acid $\left(\mathrm{NO}_{3}^{-}\right.$and $\left.\mathrm{HNO}_{3} \cdot \mathrm{NO}_{3}^{-}\right)$, MSA $\left(\mathrm{CH}_{3} \mathrm{SO}_{3}^{-}, \mathrm{CH}_{3} \mathrm{SO}_{3} \mathrm{H} \cdot \mathrm{CH}_{3} \mathrm{SO}_{3}^{-}, \mathrm{CH}_{3} \mathrm{SO}_{3} \mathrm{H} \cdot \mathrm{NO}_{3}^{-}\right.$, and $\left.\mathrm{CH}_{3} \mathrm{SO}_{3} \mathrm{H} \cdot \mathrm{HSO}_{4}^{-}\right), \mathrm{SO}_{5}^{-}$, malonic acid $\left(\mathrm{C}_{3} \mathrm{H}_{3} \mathrm{O}_{4}^{-}\right.$, $\mathrm{C}_{3} \mathrm{H}_{4} \mathrm{O}_{4} \cdot \mathrm{HSO}_{4}^{-}$, and $\mathrm{C}_{3} \mathrm{H}_{4} \mathrm{O}_{4} \cdot \mathrm{NO}_{3}^{-}$), others (identified ions, e.g., the halogen ions $\mathrm{IO}_{3}^{-}, \mathrm{Br}^{-}$), and non-identified ions. Approximately $40 \%$ of the total ion signal at the JFJ was identified for this time period. During the daytime (between 08:00 and 18:00 LST) the percentage of identified ions increases to $60 \%$ with the sulfuric acid group representing around $35 \%$ of the total ion signal. However, during the nighttime when the rate of sulfuric acid formation is very low, the charge is redistributed and the "non-identified" category becomes the most relevant. This group includes mainly the highly oxygenated organics between 450 and $1200 \mathrm{Th}$. Such compounds were also observed in the boreal forest by Ehn et al. (2010), where the signals of organic ions tended to be stronger during the nighttime (again due to less competition by the sulfuric acid clusters).

Beside malonic acid, other organic species of low molecular mass were frequently measured, like $\mathrm{C}_{3} \mathrm{H}_{5} \mathrm{O}_{3}^{-}$, $\mathrm{C}_{3} \mathrm{H}_{3} \mathrm{O}_{3}^{-}$(pyruvic acid), $\mathrm{C}_{2} \mathrm{HO}_{4}^{-}$(oxalic acid), $\mathrm{C}_{4} \mathrm{H}_{3} \mathrm{O}_{4}^{-}$, and $\mathrm{C}_{4} \mathrm{H}_{5} \mathrm{O}_{4}^{-}$. Still, malonic acid was the main organic ion not only during the day but also during the night and during clear sky and cloudy conditions. Actually, under cloudy conditions some peaks were less affected, including organics (e.g., malonic acid) and nitric acid. For the latter, we even measured its water clusters (e.g., $\mathrm{H}_{2} \mathrm{ONO}_{3}^{-} \cdot\left(\mathrm{H}_{2} \mathrm{O}\right)_{2} \cdot \mathrm{NO}_{3}^{-}$). In fact, when we sampled inside clouds (based on CSI and cameras) and during daytime, most of the ions were composed of organics clustered with $\mathrm{NO}_{3}^{-}$. Also, all sulfur-containing peaks were absent.

No significant difference was observed for the spectra in different seasons (winter and summer) except for a more frequent increase in the signals above $450 \mathrm{Th}$ attributed to organics during summertime. Considering that the JFJ is more frequently under boundary layer influence during summer (Herrmann et al., 2015), it is expected that vertical transport of air masses may carry up more organics during this season.

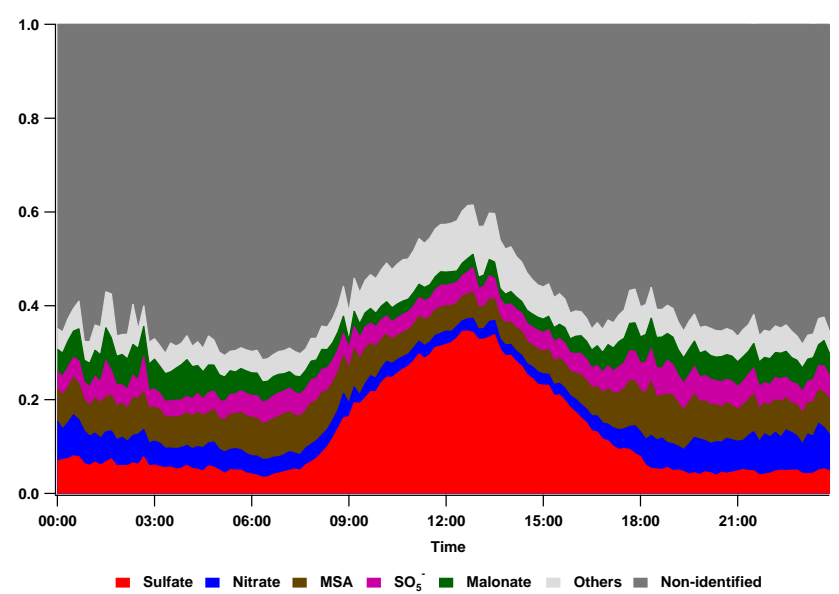

Figure 2. Average diurnal variations of the main negative ions at the JFJ over 15 days of clear sky normalized to the total negative ion count. Ions and clusters are grouped as follows: Sulfuric acid $\left(\mathrm{HSO}_{4}^{-}, \mathrm{H}_{2} \mathrm{SO}_{4} \cdot \mathrm{HSO}_{4}^{-}\right.$and $\left.\left(\mathrm{H}_{2} \mathrm{SO}_{4}\right)_{2} \cdot \mathrm{HSO}_{4}^{-}\right)$, nitric acid $\left(\mathrm{NO}_{3}^{-}\right.$ and $\left.\mathrm{HNO}_{3} \cdot \mathrm{NO}_{3}^{-}\right)$, malonic acid $\left(\mathrm{C}_{3} \mathrm{H}_{3} \mathrm{O}_{4}^{-}, \mathrm{C}_{3} \mathrm{H}_{4} \mathrm{O}_{4} \cdot \mathrm{HSO}_{4}^{-}\right.$ and $\left.\mathrm{C}_{3} \mathrm{H}_{4} \mathrm{O}_{4} \cdot \mathrm{NO}_{3}^{-}\right)$, MSA $\left(\mathrm{CH}_{3} \mathrm{SO}_{3}^{-}, \mathrm{CH}_{3} \mathrm{SO}_{3} \mathrm{H} \cdot \mathrm{CH}_{3} \mathrm{SO}_{3}^{-}\right.$, $\mathrm{CH}_{3} \mathrm{SO}_{3} \mathrm{H} \cdot \mathrm{NO}_{3}^{-}$and $\mathrm{CH}_{3} \mathrm{SO}_{3} \mathrm{H} \cdot \mathrm{HSO}_{4}^{-}$), $\mathrm{SO}_{5}^{-}$, others (identified ions) and unknown (non-identified ions including ions in the $m / z$ 450-1200 range).

We frequently detected the presence of sulfuric acid during nighttime although its rate of formation is expected to be low. Figures $1 \mathrm{~b}$ and 2 show that the signal of sulfuric acid does not disappear during the night. In addition, we observed $\sim 35$ nighttime events when the signal increased significantly with also clusters of sulfuric acid up to the tetramer being present (but never beyond the tetramer). Figure 3 presents an exemplary time series of some main ions at the JFJ. From 6 to 11 and from 15 to 18 November a typical diurnal variation of $\mathrm{HSO}_{4}^{-}$is observed which is affected by the cloud coverage (CSI $<1$, meaning clear sky) and the global radiation. The period from 11 to 14 November shows cases when sulfuric acid was also measured during the nighttime. The signal of $\mathrm{HSO}_{4}^{-}$increases due to photochemical formation around noon on 11 November after a change of wind direction and subsequent clearing up. High signals are then observed in the nights to 12 November as well as to 13 November. Although the time trend in the plot represents only $\mathrm{HSO}_{4}^{-}$, in this particular event the clusters of sulfuric acid up to the tetramer were observed. Figure 4 shows this observation in more detail with a mass defect plot and compares this event with the ion composition observed during a typical night at the JFJ. The mass defect represents the difference between the exact and the nominal mass of a compound (Th). The dots represent the main peaks, where the size of a dot is linearly proportional to the intensity of the signal and the colors represent the nature of the ions or clusters. While Fig. 4a presents a typical night (averaged between 22:00 and 02:00 LST), Fig. 4b illustrates the event of unusually high sulfuric acid signal in 


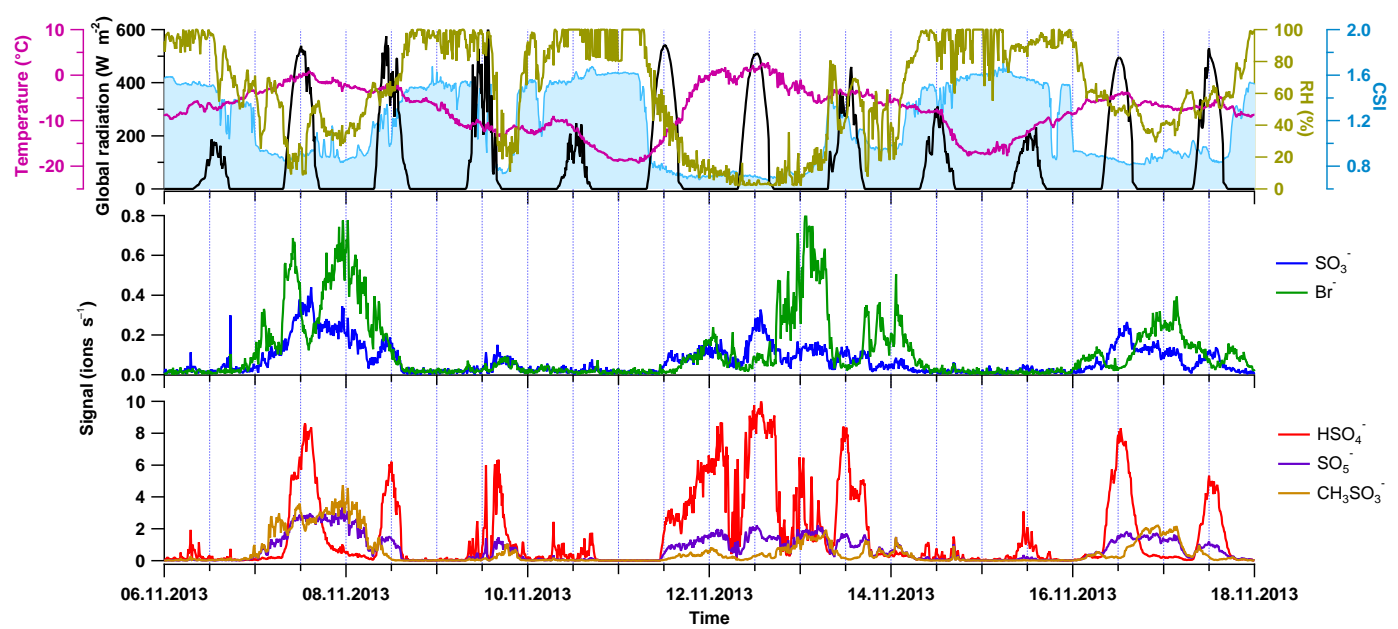

Figure 3. Time series of major ions and meteorological parameters from 6 to 18 November. Upper panel: global radiation (W $\mathrm{m}^{-2}$ ), air temperature $\left({ }^{\circ} \mathrm{C}\right)$, relative humidity $(\%)$ and clear sky index (CSI). Middle and lower panel: $\mathrm{Br}^{-}, \mathrm{SO}_{3}^{-}, \mathrm{CH}_{3} \mathrm{SO}_{3}^{-}, \mathrm{HSO}_{4}^{-}$and $\mathrm{SO}_{5}^{-}$.

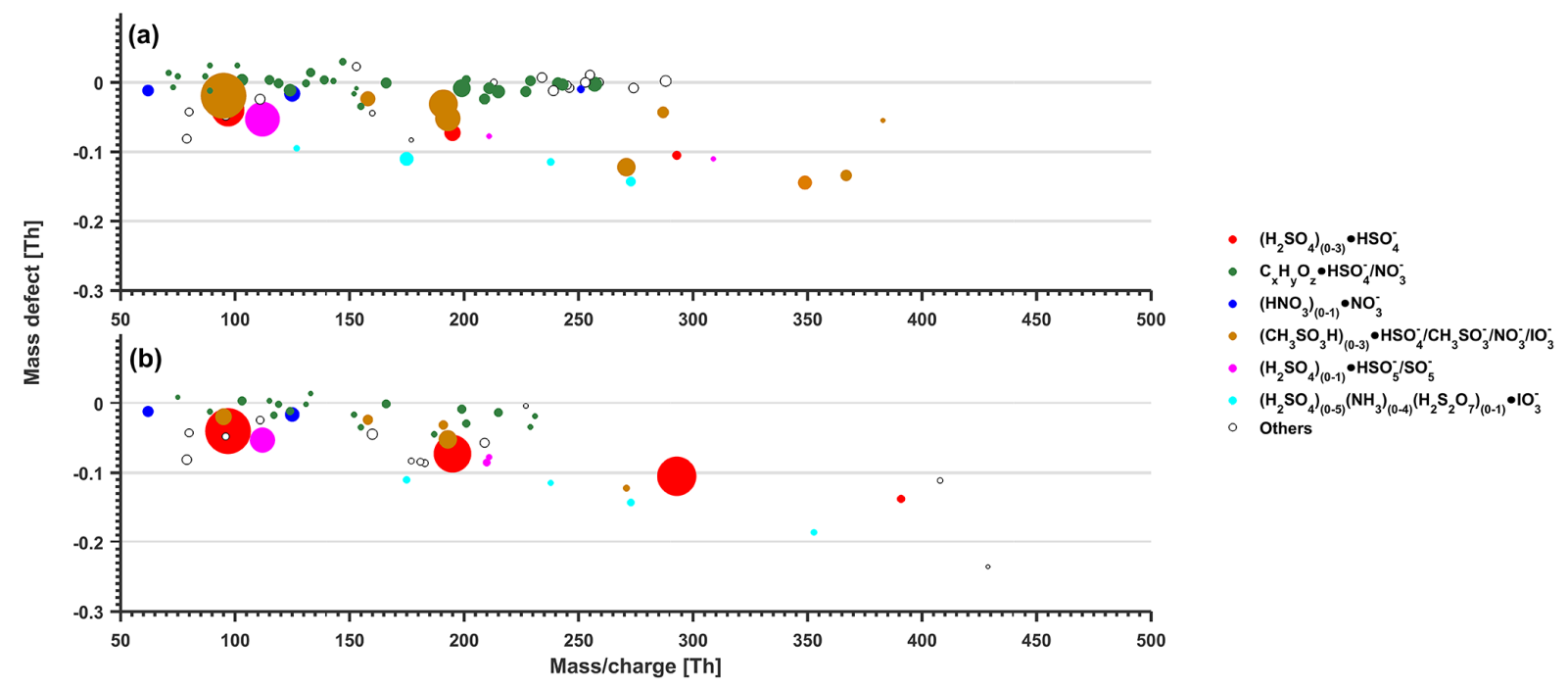

Figure 4. Comparison of two different nighttime spectra in negative mode between 22:00 and 02:00 LST. (a) Typical night spectrum, exemplified for the night from 9 to 10 March 2014. (b) Spectrum with high sulfuric acid signal in the night from 11 to 12 November 2013.

the night from 11 to 12 November. During a typical night, the main ions are composed of $\mathrm{CH}_{3} \mathrm{SO}_{3}^{-}$(brown dots) followed by $\mathrm{SO}_{5}^{-}$(pink dots). Also sulfuric acid (red dots) can be seen and even the trimer is detected in a typical nighttime spectrum $\left(\left(\mathrm{H}_{2} \mathrm{SO}_{4}\right)_{2} \mathrm{HSO}_{4}^{-}, m / z 292.8949\right)$. By contrast, in Fig. $4 \mathrm{~b}$ the main ion is sulfuric acid followed by $\mathrm{SO}_{5}^{-}$and $\mathrm{CH}_{3} \mathrm{SO}_{3}^{-}$. In this event, also the tetramer of sulfuric acid is detected $\left(\left(\mathrm{H}_{2} \mathrm{SO}_{4}\right)_{3} \mathrm{HSO}_{4}^{-}, m / z\right.$ 390.8622). Although Fig. 4a shows a typical nighttime spectrum, it is important to mention that the $\mathrm{CH}_{3} \mathrm{SO}_{3}^{-}$signal was low in some cases where the main ions were malonic and nitric acid $\left(\mathrm{NO}_{3}^{-}, \mathrm{C}_{3} \mathrm{H}_{3} \mathrm{O}_{4}^{-}\right.$, $\mathrm{HNO}_{3} \cdot \mathrm{NO}_{3}^{-}, \mathrm{C}_{3} \mathrm{H}_{4} \mathrm{O}_{3} \cdot \mathrm{NO}_{3}^{-}$).
The $\mathrm{SO}_{5}^{-}$ion was found permanently among the main anions. The first atmospheric measurements of this ion were reported by Ehn et al. (2010). They observed a close correlation between the $\mathrm{SO}_{5}^{-}$and $\mathrm{HSO}_{4}^{-}$signals in the Finnish boreal forest $\left(R^{2}>0.8\right)$, with an increase in signal correlated to global radiation. The same behavior was also observed at the JFJ $\left(R^{2}=0.88\right)$, albeit only for daytime measurements (global radiation $>550 \mathrm{~W} \mathrm{~m}^{-2}$ ). However, at the JFJ the signal of $\mathrm{SO}_{5}^{-}$was also present during clear sky nights, as shown in Fig. 3.

In addition, we found a remarkably high correlation of $\mathrm{SO}_{5}^{-}$with $\mathrm{CH}_{3} \mathrm{SO}_{3}^{-}$for the full sampling period with a $R^{2}=0.87$ during nighttime (zero global radiation) and $R^{2}=0.75$ during daytime (global radiation $>550 \mathrm{~W} \mathrm{~m}^{-2}$ ). 

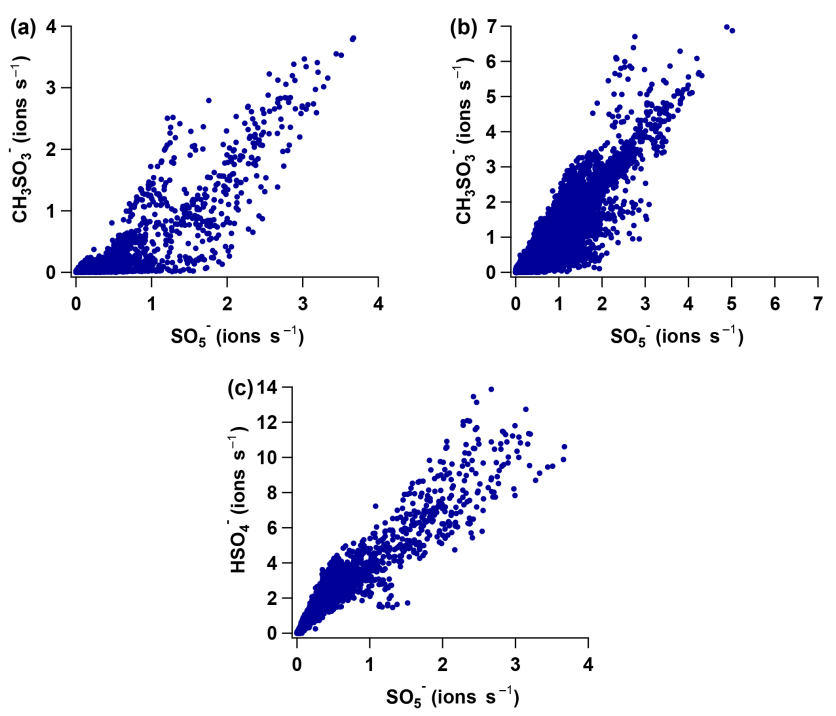

Figure 5. Correlations of $\mathrm{SO}_{5}^{-}$with $\mathrm{CH}_{3} \mathrm{SO}_{3}^{-}$and $\mathrm{HSO}_{4}^{-}$. (a) Scatter plot between $\mathrm{SO}_{5}^{-}$and $\mathrm{CH}_{3} \mathrm{SO}_{3}^{-}$ions during daytime, $y=-0.14+0.78 x$ and $R^{2}=0.75$. (b) Scatter plot between $\mathrm{SO}_{5}^{-}$and $\mathrm{CH}_{3} \mathrm{SO}_{3}^{-}$ions during nighttime, $y=0.028+1.24 x$ and $R^{2}=0.87$. (c) Scatter plot between $\mathrm{SO}_{5}^{-}$and $\mathrm{HSO}_{4}^{-}$ions during daytime, $y=0.468+3.49 x$ and $R^{2}=0.88$.

No special dependencies on boundary layer influence (based on Herrmann et al., 2015) were found. The correlation is plotted in Fig. 5 for day and nighttime. As shown in the same figure, a high correlation between $\mathrm{SO}_{5}^{-}$and $\mathrm{HSO}_{4}^{-}$is also seen during daytime. Comparing Fig. $5 \mathrm{a}$ and $\mathrm{b}$ it seems that the correlation of $\mathrm{SO}_{5}^{-}$with $\mathrm{CH}_{3} \mathrm{SO}_{3}^{-}$during day is offset to higher $\mathrm{SO}_{5}^{-}$, implying an additional mechanism forming $\mathrm{SO}_{5}^{-}$during the day. This is further discussed in Sect. 3.3.2 below.

\subsection{Halogenated species}

Naturally occurring halogenated species in the atmosphere are usually linked to measurements in the marine boundary layer (MBL), especially for chloride and bromide, which are contained in seawater. Compared to chloride and bromide, iodide is usually observed at lower signals since it is incorporated as a nutrient by biological processes. Inorganic iodine originates from the decomposition of natural iodocarbons such as $\mathrm{CH}_{3} \mathrm{I}$ and $\mathrm{CH}_{2} \mathrm{I}_{2}$ and the inorganic precursors HOI and $\mathrm{I}_{2}$ (Simpson et al., 2015). Several studies have reported the presence of iodine oxide at different locations in the MBL. Simpson et al. (2015) summarized these observations which include measurements at Tenerife, Tasmania, Cape Verde, West Pacific, and East Pacific. To our knowledge, there are no reports of bromide or iodide and its oxides in the atmosphere of continental and high altitude locations similar to the Jungfraujoch (at $3500 \mathrm{~m}$ a.s.l. and around $250 \mathrm{~km}$ from the nearest coastal region in the Mediterranean).
The halogenated species $\mathrm{CF}_{3}^{-}, \mathrm{Br}^{-}, \mathrm{IO}_{3}^{-}, \mathrm{HNO}_{3} \cdot \mathrm{IO}_{3}^{-}$, $\mathrm{CH}_{3} \mathrm{HSO}_{3} \cdot \mathrm{IO}_{3}^{-}$, and $\mathrm{H}_{2} \mathrm{SO}_{4} \cdot \mathrm{IO}_{3}^{-}$were detected regularly at the JFJ. The maximum signal of these ions was generally observed during 07:00-09:00 and 17:00-21:00 LST, but occasionally high signals were also detected during nighttime (22:00-04:00 LST). Figure 6 shows this temporal variation with the main species, $\mathrm{IO}_{3}^{-}$and $\mathrm{Br}^{-}$, from 11 to 16 March 2014 (for additional time series see also Fig. 7c). The figure also presents the signals of $\mathrm{HSO}_{4}^{-}, \mathrm{CH}_{3} \mathrm{SO}_{3}^{-}$, and $\mathrm{SO}_{5}^{-}$as well as global radiation, $\mathrm{RH}$, and the cloud coverage (CSI) to provide an overview over the ambient conditions. The clear peaks in signal, mainly of $\mathrm{IO}_{3}^{-}$, during sunrise and sunset and the strong decrease during noon suggests the occurrence of efficient photochemical halogen chemistry. The process could be initiated by the so-called halogen reservoir species $X_{2}, \mathrm{HO} X, X \mathrm{NO}_{2}$, or $\mathrm{H} X$, with $X$ being the halogen atom.

$X_{2}, \mathrm{HO} X, X \mathrm{NO}_{2}, \mathrm{HX} \stackrel{\mathrm{OH}, \mathrm{HO}_{2}, h v}{\longrightarrow} X \cdot+$ products

The depletion of the ions is then presumably the result of photolysis or the reaction of their parent compound with halogen atoms or $\mathrm{OH} \cdot$ radicals. Nevertheless, the observed diurnal pattern may also be due to charge redistribution between iodic and sulfuric acid, as the latter has a strong diurnal variation (see above) and effectively competes for the limited charge. However, without measurements of neutral species it is not possible to discriminate between these two possibilities.

An additional observation in Fig. 6 is the trend of $\mathrm{CH}_{3} \mathrm{SO}_{3}^{-}$ which anticorrelates with sulfuric acid and rather follows the trend of $\mathrm{IO}_{3}^{-}$and $\mathrm{Br}^{-}$. From 12 to 15 March the solar radiation was strong and the $\mathrm{RH}$ low, producing a typical diurnal cycle of sulfuric acid. However, the $\mathrm{CH}_{3} \mathrm{SO}_{3}^{-}$signal decreases during the peaks of sulfuric acid and only increases around 18:00 LST following the recovery of $\mathrm{IO}_{3}^{-}$and $\mathrm{Br}^{-}$. $\mathrm{SO}_{5}^{-}$follows a similar trend as $\mathrm{CH}_{3} \mathrm{SO}_{3}^{-}$but less pronounced. This has to do with additional pathways of $\mathrm{SO}_{5}^{-}$as discussed below. The close relationship of the time trends of MSA with $\mathrm{Br}^{-}$and $\mathrm{IO}_{3}^{-}$could indicate a mechanistic connection between these species, for example a formation of MSA linked with halogen-based chemistry. However, it can also be simply caused by charge redistribution to sulfuric acid generating a similar diurnal trend.

The presence of these halogen species suggests that air masses of marine origin were transported towards the JFJ. Backward dispersion calculations were carried out with the FLEXPART model (see Sect. 2.3) for days when the signal of the main ion $\mathrm{IO}_{3}^{-}$was equal to or higher than the 95th percentile of all its values during this campaign (24 events in total). During these events other iodine species were also detected, as described below. The transport simulations revealed that the air masses had an extended surface residence time over the Atlantic Ocean and occasionally also over the Arctic, Mediterranean Sea, and continental regions. Figure 7 


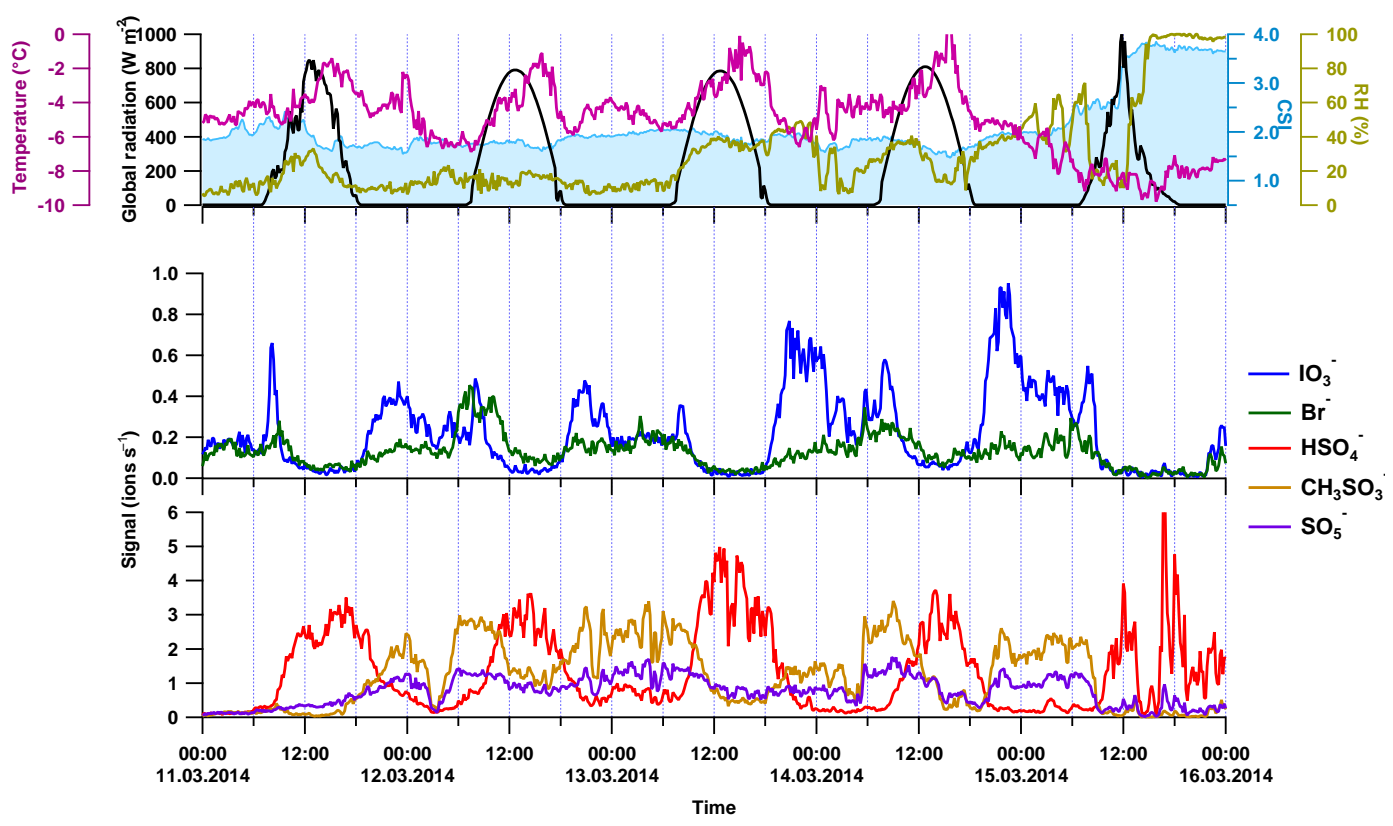

Figure 6. Time series from 11 to 16 March illustrating halogen chemistry. Global radiation, RH and cloud coverage are shown in the top panel. The decrease in signal of $\mathrm{Br}^{-}$and $\mathrm{IO}_{3}^{-}$during noon in the middle panel implies photochemical reactions on the precursors of these ions or charge distribution. The lowest panel shows the anticorrelation of sulfuric acid with $\mathrm{CH}_{3} \mathrm{SO}_{3}^{-}$and $\mathrm{SO}_{5}^{-}$.

shows two events when the halogen signals increased, specifically for $\mathrm{Br}^{-}$and $\mathrm{IO}_{3}^{-}$. Figure 7a shows the temporal evolutions of the ion signal on 2 October 2013 while Fig. $7 \mathrm{~b}$ shows the surface residence time back trajectories for the same period of time. Figure $7 \mathrm{~b}$ is divided into two subplots, i.e., an absolute footprint, $\tau$, in $\mathrm{s} \mathrm{m}^{-3} \mathrm{~kg}^{-1}$ (left) and a relative footprint $R(\%)$ (right). The first refers to the amount of time that an air mass stays at the surface, whereas the second is calculated as the difference between the mean event footprint and the mean footprint over the whole simulation period (one year) divided by the mean of these two. The relative presentation usually assists the identification of special features of a certain transport situation without being dominated by the generally decreasing residence time with distance to the site. Areas with negative (positive) values of the relative footprint correspond to areas with weaker (stronger) surface sensitivity than the annual average. The event shown in Fig. $7 \mathrm{~b}$ represents a case in which the air mass sampled at JFJ was dominated by above average surface contacts over the Atlantic Ocean. This event represents a frequently occurring transport of air masses from the Atlantic Ocean towards the JFJ. Similarly, Fig. 7c shows the time series of elevated halogen ion signals during an event on 16-17 November 2013 where the air masses arrived from continental areas with possible influence from the eastern Mediterranean Sea. This type of transport was less frequent, with a total of 6 events out of the total 24. Although most of the backward simulations suggest a marine and coastal origin of the precursors of halogenated ions, we do not discard the possible contribution from conti- nental regions as it is also observed from Fig. 7d. A combined footprint of all the events with high halogen signal at the Jungfraujoch is presented in Fig. 8. This combined inverse-time calculation confirms that air masses are transported mainly from the Atlantic Ocean and even from the US east coast.

The detection of ions and clusters of marine origin is potentially relevant due to their observed participation in new particle formation (O'Dowd et al., 2002). However, no new particle formation events were observed at the JFJ where halogen species were involved in cluster growth (see below), even though these ions were detected frequently. This would imply that halogens may be "spectators" at high altitude, i.e., ions that are present, but do not participate in new particle formation.

\subsubsection{Iodine species}

Besides $\mathrm{IO}_{3}^{-}$, its clusters with $\mathrm{H}_{2} \mathrm{SO}_{4}$ and $\mathrm{CH}_{3} \mathrm{SO}_{3} \mathrm{H}$ and organics (e.g., $\mathrm{C}_{7} \mathrm{H}_{15} \mathrm{~N} \cdot \mathrm{IO}_{3}^{-}$) were observed. Several other iodine species were also found at the JFJ. These included $\mathrm{I}^{-}$, $\mathrm{IO}^{-}, \mathrm{IO}_{2}^{-}$, and clusters of $\mathrm{I}_{2} \mathrm{O}_{3}$ and $\mathrm{I}_{2} \mathrm{O}_{5}$ with ions of sulfuric acid or MSA (e.g., $\mathrm{I}_{2} \mathrm{O}_{5} \cdot \mathrm{CH}_{3} \mathrm{SO}_{3}^{-}$). The observation of $\mathrm{I}_{2} \mathrm{O}_{5}$ in clusters with $\mathrm{CH}_{3} \mathrm{SO}_{3}^{-}$and sulfuric acid confirms the presence of $\mathrm{I}_{2} \mathrm{O}_{5}$ in the atmosphere which was proposed from laboratory and modeling studies (Saunders and Plane, 2005). However, to our knowledge no studies have reported the presence of $\mathrm{I}_{2} \mathrm{O}_{5}$ in the atmosphere up to now. Saunders and Plane (2005) speculated that $\mathrm{I}_{2} \mathrm{O}_{5}$ could be photo- 
(a)

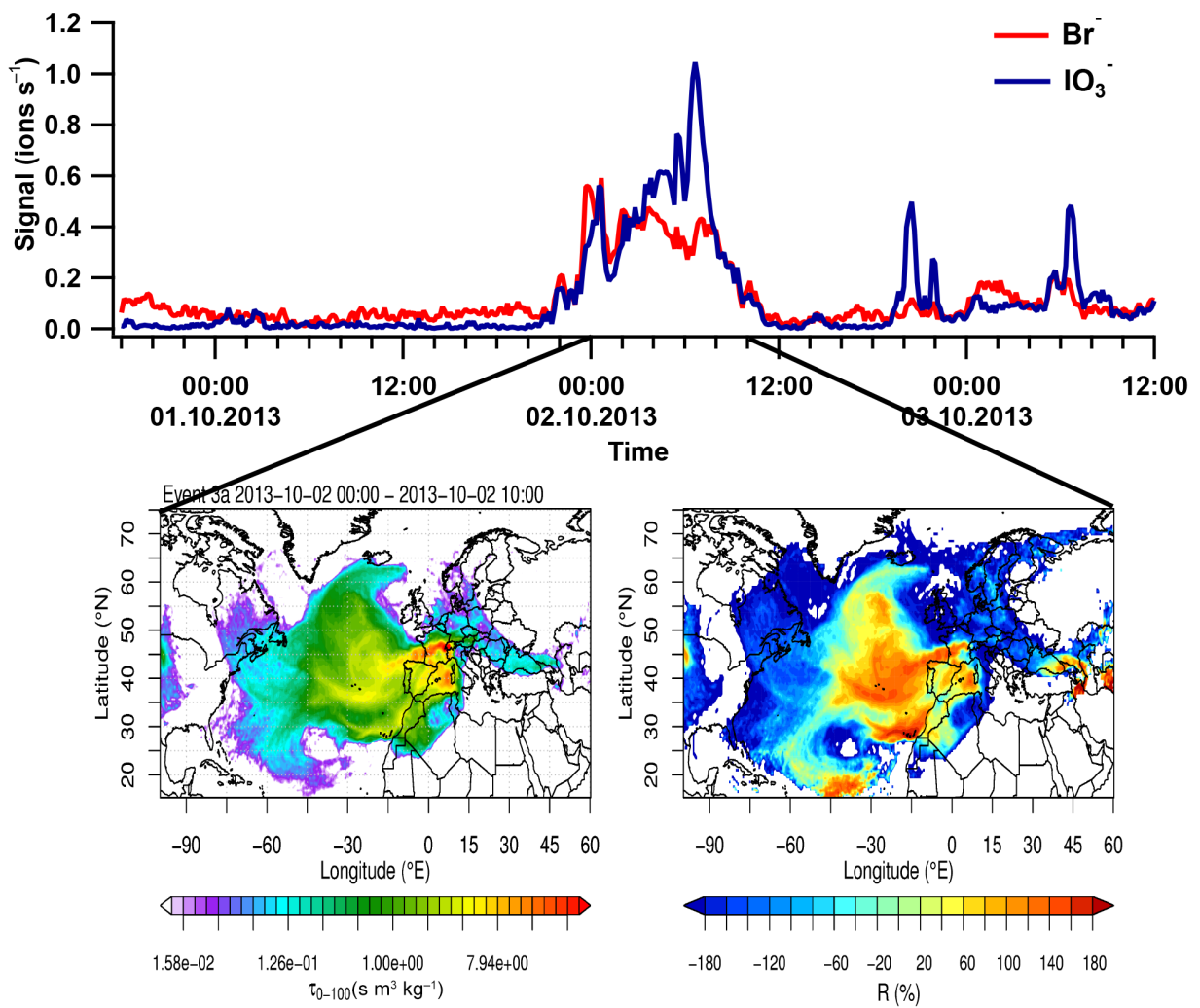

(c)

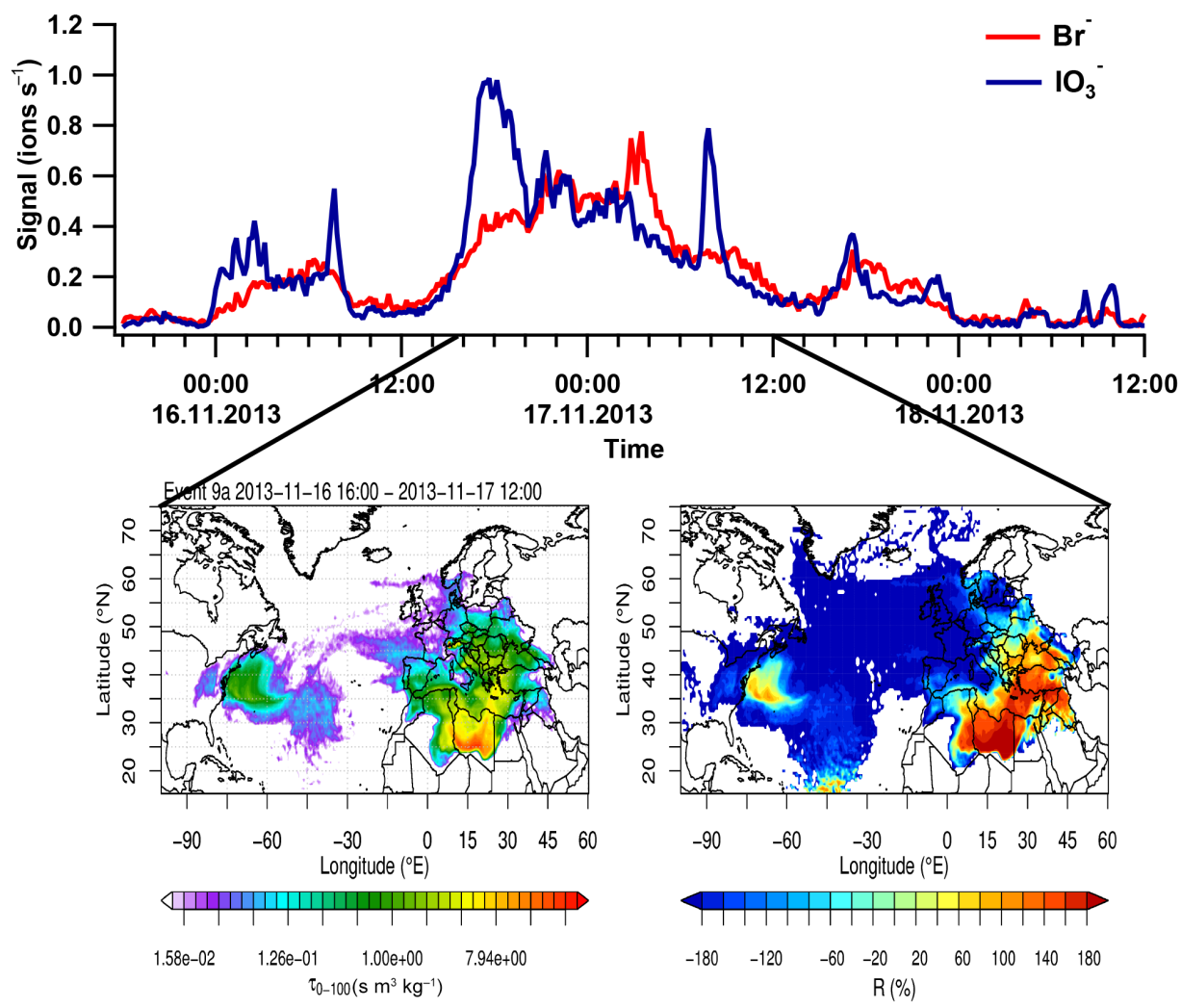

Figure 7. Examples of two events with high $\mathrm{Br}^{-}$and $\mathrm{IO}_{3}^{-}$signal and back trajectories for surface residence time. (a, b) Air masses from the Atlantic, (c, d) air masses from the Mediterranean. The black lines denote the time period for the trajectory analyses shown in (b) and (d). 

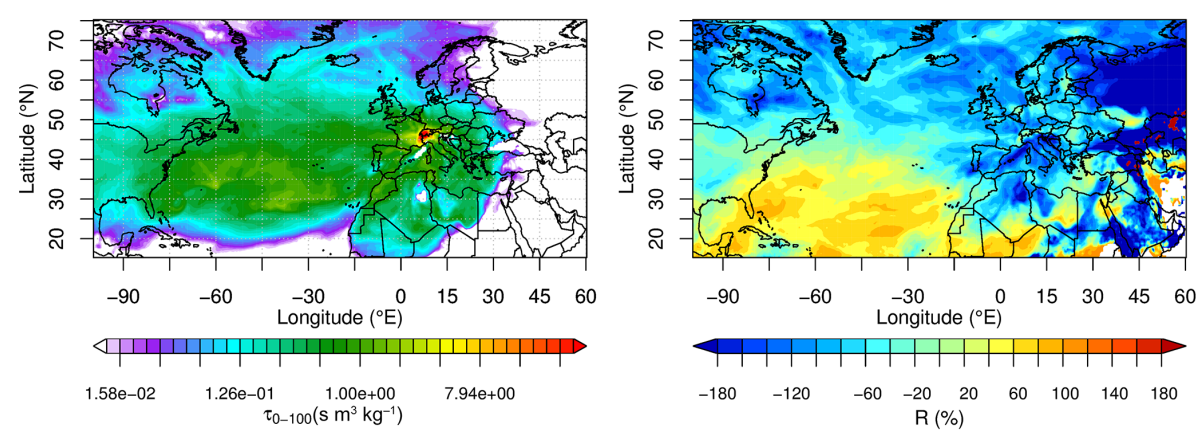

Figure 8. Combined footprint from all events with high halogen signal $\left(\mathrm{IO}_{3}^{-}\right.$and $\left.\mathrm{Br}^{-}\right)$.

chemically formed via an oxidation chain of iodine atoms with $\mathrm{O}_{3}$ in the gas phase:

$\mathbf{I}+\mathrm{O}_{3} \rightarrow \mathbf{I O}+\mathrm{O}_{2}$

$\mathrm{IO}+\mathrm{IO} \rightarrow \mathrm{OIO}+\mathrm{I}$

$\mathrm{IO}+\mathrm{IO} \rightarrow \mathrm{I}_{2} \mathrm{O}_{2}$

$\mathbf{I O}+\mathrm{OIO}(+M) \rightarrow \mathbf{I}_{2} \mathbf{O}_{3}$

$\mathrm{OIO}+\mathrm{OIO}(+M) \leftrightarrow \mathrm{I}_{2} \mathrm{O}_{4}$

$\mathrm{I}_{2} \mathrm{O}_{2}+\mathrm{O}_{3} \rightarrow \mathbf{I}_{2} \mathbf{O}_{3}+\mathrm{O}_{2}$

$\mathbf{I}_{2} \mathrm{O}_{3}+\mathrm{O}_{3} \rightarrow \mathrm{I}_{2} \mathrm{O}_{4}+\mathrm{O}_{2}$

$\mathrm{I}_{2} \mathrm{O}_{4}+\mathrm{O}_{3} \rightarrow \mathbf{I}_{2} \mathrm{O}_{5}+\mathrm{O}_{2}$.

In this oxidation chain, the molecules detected at the JFJ as clusters with $\mathrm{CH}_{3} \mathrm{SO}_{3}^{-}, \mathrm{NO}_{3}^{-}$, or $\mathrm{HSO}_{4}^{-}$are in bold. According to quantum chemical calculations by Kaltsoyannis and Plane (2008), $\mathrm{I}_{2} \mathrm{O}_{4}$ would have a lower stability in the atmosphere compared to the other iodine-containing species. This may be the reason why we did not observe this species. Saunders and Plane (2005) assumed that iodine atoms are formed by a photochemical process. However, for $\mathrm{IO}_{2} \mathrm{I}_{2} \mathrm{O}_{3}$, and $\mathrm{I}_{2} \mathrm{O}_{5}$ we observed a similar time trend as for $\mathrm{IO}_{3}^{-}$with a strong decrease during the day (see Fig. 6). This is further indication of nighttime halogen chemistry. However, without the measurement of neutral species we do not have the quantitative concentration data to further elucidate this process.

\subsection{Production of sulfur-containing species}

In this section we provide some hypotheses to explain the observed formation of sulfuric acid during the nighttime and the observed correlation between $\mathrm{CH}_{3} \mathrm{SO}_{3}^{-}$and $\mathrm{SO}_{5}^{-}$. Even though our measurements are restricted to ions, we believe that species such as sulfuric acid and MSA are formed as neutral channel species. The diurnal cycle of $\mathrm{HSO}_{4}^{-}$presented in Fig. 2, for example, is a clear indication that the ion follows the sulfuric acid concentration. Also, the presence of clusters of the type $\left(\mathrm{H}_{2} \mathrm{SO}_{4}\right)_{1-3} \mathrm{HSO}_{4}^{-}$or $\left(\mathrm{CH}_{3} \mathrm{SO}_{3} \mathrm{H}\right)_{1-3} \mathrm{CH}_{3} \mathrm{SO}_{3}^{-}$(shown in Fig. 4) is another strong indication of the presence of neutral molecules.

\subsubsection{Sulfuric acid during nighttime}

The most important gas phase pathway for the production of sulfuric acid occurs via the reaction of $\mathrm{SO}_{2}$ with the $\mathrm{OH}$ radical (Stockwell and Calvert, 1983) and is the reason for the well-known diurnal cycle of sulfuric acid:

$\mathrm{SO}_{2}+\mathrm{OH}+M \rightarrow \mathrm{HOSO}_{2}+M$,

$\mathrm{HOSO}_{2}+\mathrm{O}_{2} \rightarrow \mathrm{HO}_{2}+\mathrm{SO}_{3}$,

$\mathrm{HOSO}_{2}+\mathrm{O}_{2} \rightarrow \mathrm{HSO}_{5}$,

$\mathrm{SO}_{3}+\mathrm{H}_{2} \mathrm{O}+M \rightarrow \mathrm{H}_{2} \mathrm{SO}_{4}+M$,

where $M$ is a stabilizing (energy-absorbing) molecule, usually $\mathrm{N}_{2}$ or $\mathrm{O}_{2}$. However, this reaction cannot explain sulfuric acid formation during nighttime observed in a total of 35 events at the JFJ with especially high signals (with clusters up to the tetramer). An alternative production of sulfuric acid during nighttime can take place through the Criegee intermediates (CIs); CIs have been observed in field measurements in a boreal forest (Mauldin III et al., 2012) and at coastal regions (Berresheim et al., 2014) and can be formed through the ozonolysis of double bonds containing compounds (alkenes):

$\mathrm{O}_{3}+$ alkene $\rightarrow$ Criegee intermediate $(\mathrm{CI})$.

(R13)

About half of the CIs in Reaction (R13) decompose and produce $\mathrm{OH}$. In this case the $\mathrm{SO}_{2}$ oxidation chain can proceed as shown in Reactions (R10), (R11a), and (R12) producing sulfuric acid. The other half of the CIs are stabilized, producing stabilized Criegee radicals (sCI) which decompose over a much longer lifetime. These sCI are able to oxidize $\mathrm{SO}_{2}$ and therefore produce sulfuric acid (Mauldin III et al., 2012). Alkenes can be transported to the free troposphere by injection of polluted air masses from the planetary boundary layer. Such an injection also decreases the $\mathrm{CO} / \mathrm{NO}_{y}$ ratio, which is used as a proxy for the age of an air mass since boundary layer contact (Zellweger et al., 2003). The nighttime sulfuric acid signal was not correlated with the $\mathrm{CO} / \mathrm{NO}_{y}$ ratio; therefore it is possible that Criegee intermediates are not 

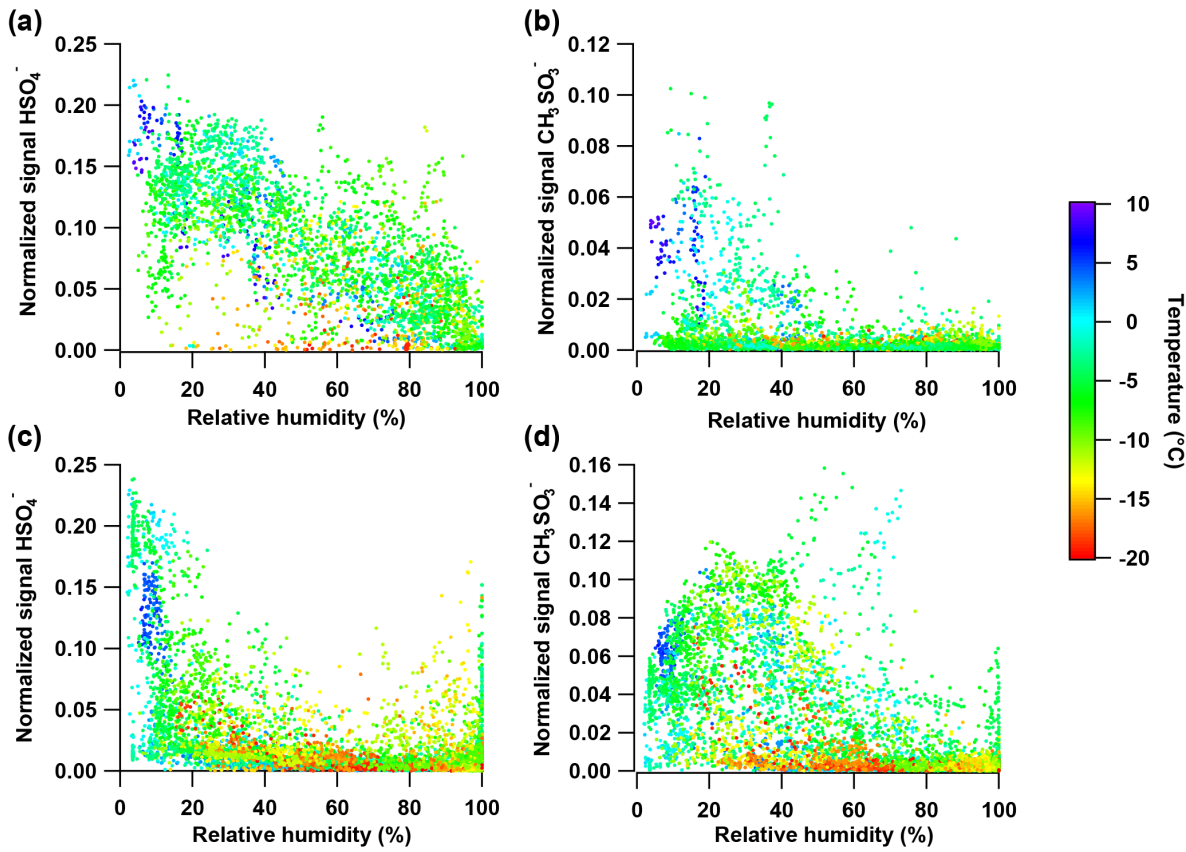

Figure 9. Dependence of $\mathrm{HSO}_{4}^{-}$and $\mathrm{CH}_{3} \mathrm{SO}_{3}^{-}$on relative humidity, as a function of temperature during the daytime (a, b) and nighttime (c, d). The signal was normalized to the total ion counts.

the main mechanism for nighttime sulfuric acid formation at the JFJ. We do not discard, however, the possible transport of isoprene or terpenes from rural areas not detected by the $\mathrm{CO} / \mathrm{NO}_{y}$ ratio.

Besides CIs, we also explored the possibility of particlegas partitioning from preexisting particles leading to an increase of sulfuric acid in the gas phase. Figure $9 \mathrm{a}$ and c summarize the signal of sulfuric acid during day and nighttime as function of relative humidity and temperature. During the day under photolytic production its steady state concentration is strongly decreasing from low to high RH. At night, higher signals are observed below $40 \% \mathrm{RH}$ and temperatures above $-5^{\circ} \mathrm{C}$. Regarding the events when a high signal of sulfuric acid was observed during night, 14 out the 35 events were characterized by a significant drop in RH to levels in the range of 3-27\% with an increase in temperature (never exceeding $5{ }^{\circ} \mathrm{C}$ ). One example of these events is given in Figs. 3 and 4. For these events we considered the possibility of stratospheric intrusion as the reason for the drop in RH. During these events the ozone concentration did not change significantly (65-90 ppbv) except for five of the events when $\mathrm{O}_{3}$ increased to levels between 103 and $130 \mathrm{ppbv}$. However, an $\mathrm{O}_{3}$ concentration in the range of $70-90 \mathrm{ppbv}$ was observed in the Alpine region by Stohl et al. (2000) during stratospheric intrusion events; therefore $\mathrm{O}_{3}$ cannot be considered a strong marker of a stratospheric intrusion at the JFJ. The radon concentration (Institute of Environmental Geosciences, University of Basel, http://azug.minpet.unibas.ch) was also investigated in order to detect a stratospheric intrusion, but no significant variation of radon was observed.

From the remaining events with high sulfuric acid signal during nighttime, 5 events had an RH between 38 and $62 \%$ and 16 events a RH between 72 and $99 \%$. These events were characterized by snowfall; consequently we believe that evaporation of sulfuric acid from snowflakes occurred in the inlet of the APi-TOF because of an increase in temperature between ambient conditions and the laboratory. Therefore, we conclude that all the events of high sulfuric acid during nighttime that we measured resulted from the evaporation from the particle phase due to a decrease in relative humidity and/or increase in temperature either in the atmosphere (events with low RH) or in the instrument (events with high RH). Indeed, the former process is well known. As an example, Mauldin III et al. (1999) observed an increase in the gas phase concentration of $\mathrm{H}_{2} \mathrm{SO}_{4}$ with decreasing $\mathrm{RH}$ during evening and nighttime flights over the Pacific. The measured $\mathrm{H}_{2} \mathrm{SO}_{4}$ concentrations were approximately a factor of 10 higher $\left(\sim 1 \times 10^{6}\right.$ to $\left.10-11 \times 10^{6} \mathrm{~cm}^{-3}\right)$ when the aircraft flew in dryer layers of air $(\mathrm{RH}<10 \%$ and temperature $\sim-3^{\circ} \mathrm{C}$ ). They confirmed these observations with models and laboratory measurements showing that $\mathrm{H}_{2} \mathrm{SO}_{4}$ evaporates from the particle phase at low $\mathrm{RH}$. Recently, Tsagkogeorgas et al. (2016) found in the CLOUD chamber, with experiments at RH between 0.3 and $10 \%$ and temperatures between -5 and $20^{\circ} \mathrm{C}$, that a decrease in $\mathrm{RH}$ and/or an increase in temperature induces particle shrinkage by evaporation of sulfuric acid, resulting in almost 1 order of magnitude 
higher concentrations of sulfuric acid in the gas phase with respect to the background.

\subsubsection{Methanesulfonic acid and peroxomonosulfate radical $\left(\mathrm{SO}_{5}^{-}\right)$}

The peroxomonosulfate radical $\left(\mathrm{SO}_{5}^{-}\right)$was first measured in the laboratory as a product from the reaction of $\mathrm{O}_{3}^{-}$or $\mathrm{CO}_{3}^{-}$ with $\mathrm{SO}_{2}$ (Möhler et al., 1992; Salcedo et al., 2004) according to

$$
\begin{aligned}
\mathrm{CO}_{3}^{-} \cdot n \mathrm{H}_{2} \mathrm{O} & +\mathrm{SO}_{2} \rightarrow \mathrm{SO}_{3}^{-} \cdot m \mathrm{H}_{2} \mathrm{O} \\
& +\mathrm{CO}_{2}+(n-m) \mathrm{H}_{2} \mathrm{O} \\
\mathrm{SO}_{3}^{-} \cdot n \mathrm{H}_{2} \mathrm{O} & +\mathrm{O}_{2} \rightarrow \mathrm{SO}_{5}^{-} \cdot m \mathrm{H}_{2} \mathrm{O}+(n-m) \mathrm{H}_{2} \mathrm{O}
\end{aligned}
$$

with $0<n<2$. Reaction ( $\mathrm{R} 14$ ) could also take place with $\mathrm{O}_{3}^{-}$ instead of $\mathrm{CO}_{3}^{-}$.

Bork et al. (2013) concluded from quantum chemical calculations that the distance and the strength of the $\mathrm{O}_{2}-\mathrm{SO}_{3}^{-}$ bond resembles more a molecular cluster than a covalentlybound molecule. A reanalysis of the data from the CLOUD chamber presented by Schobesberger et al. (2015) reveals the presence not only of $\left(\mathrm{NH}_{3}\right)_{m}\left(\mathrm{H}_{2} \mathrm{SO}_{4}\right)_{n} \mathrm{HSO}_{5}^{-}$clusters but also $\left(\mathrm{NH}_{3}\right)_{m}\left(\mathrm{H}_{2} \mathrm{SO}_{4}\right)_{n} \mathrm{SO}_{5}^{-}$, suggesting that $\mathrm{SO}_{5}^{-}$as well as $\mathrm{HSO}_{5}^{-}$are most likely molecules rather than clusters. The binding of ammonia-sulfuric acid molecules occurs via strong hydrogen bonds and we believe it is unlikely that $\mathrm{SO}_{5}^{-}$ could be bound by an additional interaction of the type $\mathrm{SO}_{3}^{-}$$\mathrm{O}_{2}$ with $\left(\mathrm{NH}_{3}\right)_{m}\left(\mathrm{H}_{2} \mathrm{SO}_{4}\right)_{n}$.

Reactions (R14) and (R15) could explain the observations of $\mathrm{SO}_{5}^{-}$during the day and night at the JFJ. The correlation of $\mathrm{SO}_{5}^{-}$with $\mathrm{CH}_{3} \mathrm{SO}_{3}^{-}$shown in the previous section implies another strong source of $\mathrm{SO}_{5}^{-}$with a common precursor for these two ions. It is important to note that although we measured ions, the presence of MSA clusters is a strong indication of neutral chemistry involved in the formation of MSA (Figs. 1 and 4).

Traditionally, the oxidation of dimethyl sulfide (DMS) is considered the exclusive source of MSA (Seinfeld and Pandis, 2006). Since DMS is mainly produced by marine phytoplankton, MSA is also related to marine emissions. Since oxidation of DMS produces both MSA and $\mathrm{SO}_{2}$, a correlation between MSA and $\mathrm{SO}_{5}^{-}$could be envisaged based on the Reactions (R14) and (R15). However, this would imply that the contribution of anthropogenic $\mathrm{SO}_{2}$ sources is small, in contradiction with studies showing that the JFJ is influenced by regional sources and PBL air masses (Herrmann et al., 2015; Bukowiecki et al., 2016; and references therein). Although the production of MSA derived from DMS is a photochemical process we did not observe a clear diurnal pattern in the MSA signal similar to sulfuric acid. MSA is often anticorrelated to sulfuric acid as discussed above (Sect. 3.2 and Fig. 6). Berresheim et al. (2002) did observe fluctuating behavior of MSA overlapping the diurnal photochemical formation at Mace Head (Ireland). They attributed this to a sensitive dependence of the gas-particle partitioning on RH or temperature. During daytime we observed elevated MSA in the gas phase at low RH but during nighttime no clear dependence on $\mathrm{RH}$ or temperature (except for very low temperature) was observed (Fig. $9 \mathrm{~b}$ and d). Due to the variation in partitioning of MSA, a high correlation with the independent formation of $\mathrm{SO}_{5}^{-}$(Reactions R14 and R15) seems questionable. As seen from Fig. 5c, during sunny days sulfuric acid and $\mathrm{SO}_{5}^{-}$are well correlated. This fraction of $\mathrm{SO}_{5}^{-}$was presumably formed from deprotonation of the peroxyradical $\mathrm{HSO}_{5}$. This radical may be formed from another pathway of Reaction (R11), that is by addition of $\mathrm{O}_{2}$ to $\mathrm{HSO}_{3}$ (Reaction $\mathrm{R} 11 \mathrm{~b}$ ) rather than $\mathrm{H}$-abstraction (Gleason et al., 1987). This pathway seems reasonable as also $\mathrm{HSO}_{5}^{-}$is observed. $\mathrm{H}_{2} \mathrm{SO}_{5}$ can be formed from the reaction $\mathrm{HSO}_{5}+\mathrm{HO}_{2}$. As seen in Fig. 5a the $\mathrm{SO}_{5}^{-}$produced by this mechanism shifts the $\mathrm{MSA}-\mathrm{SO}_{5}^{-}$correlation to higher $\mathrm{SO}_{5}^{-}$values during the day. Thus, there are three possible formation pathways of $\mathrm{SO}_{5}^{-}$: (a) Reactions (R.14) and (R15) occurring all the time, (b) deprotonation of $\mathrm{HSO}_{5}$, or (c) unknown process correlated with the formation of $\mathrm{CH}_{3} \mathrm{SO}_{3}^{-}$. The last process seems to be not directly influenced by photolysis. The measurement of the neutral species could shed some more light on this. Previous studies claim that there might be a missing source of MSA (Bardouki et al., 2003; Mauldin et al., 2003). Mauldin et al. (2003) and references therein speculate about the oxidation of DMS involving halogen chemistry or the production of MSA by oxidation of species other than DMS (e.g., DMSO) to explain MSA measurements during nighttime. Bardouki et al. (2003) suggest heterogeneous reactions of DMSO on aerosols as a source of particulate methylsulfonate. Our observations shown in Fig. 6 could support the hypothesis of a mechanism involving halogen chemistry. Often MSA decreases concurrently with the halogen species $\mathrm{Br}^{-}$and $\mathrm{IO}_{3}^{-}$during the day while all three species are observed during the night. It is also interesting to note that we often observed methyl bisulfate $\left(\mathrm{CH}_{4} \mathrm{O}_{4} \mathrm{~S}^{-}, 110.9758 \mathrm{Th}\right)$ at the JFJ, which to our knowledge has not been reported in the atmosphere. We may speculate that the formation of methyl bisulfate and MSA proceeds via a similar reaction.

\subsection{New particle formation events}

During the whole period of measurement ( $\sim 9$ months) we identified more than 30 NPF events. From these events, some were not measured with the APi-TOF due to technical difficulties. In total, 26 events were registered from which we identified two types of NPF processes: one involving sulfuric acid-ammonia clusters $\left(\mathrm{H}_{2} \mathrm{SO}_{4}-\mathrm{NH}_{3}, 7\right.$ events $)$ and one through highly oxygenated molecules (HOMs, 19 events). The first of these is well established and has been observed regularly in the atmosphere (e.g., Zhao et al., 2011). Occasionally, the sulfuric acid-ammonia clusters were also observed during days with no NPF. In these cases, the clusters 


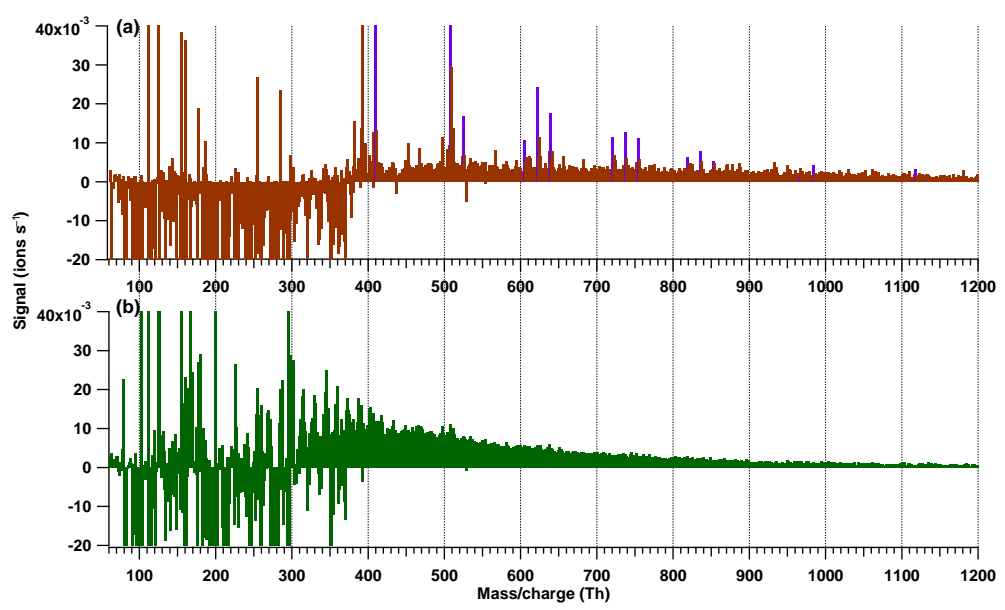

Figure 10. Difference of the negative mode mass spectra between two types of new particle formation and the average of 21 non-new particle formation sunny days (average signal of nucleation days - non-nucleation days). (a) 7 new particle formation events with $\mathrm{H}_{2} \mathrm{SO}_{4}$ $\mathrm{NH}_{3}$ clusters (purple peaks); (b) 19 new particle formation events with HOMs.

did not grow beyond $\sim 2 \mathrm{~nm}$, obviously because not sufficient condensable material was present.

The second type of event, triggered by HOMs, was observed more frequently at the Jungfraujoch, where almost all the measured organic molecules were highly oxygenated, with an $\mathrm{O}: \mathrm{C}$ ratio between 1 and 1.25 (see also Bianchi et al., 2016). Kirkby et al. (2016) showed in laboratory experiments that new particle formation of HOMs can also proceed without participation of sulfuric acid. Our data (Bianchi et al., 2016) confirm that this also happens in the ambient atmosphere, as the HOMs normally are mostly clustered with $\mathrm{NO}_{3}^{-}$and only very rarely with $\mathrm{HSO}_{4}^{-}$, suggesting that the major pathway of new particle formation was through the HOMs while sulfuric acid contributed only to a minor extent to this new particle formation.

Figure 10 presents the difference between the average spectra of each of these two types of new particle formation events and the average spectrum of 21 sunny days without new particle formation (Fig. 10a for the 7 events with sulfuric acid-ammonia clusters and Fig. 10b for the 19 events with HOMs). For this figure, the spectrum during was deducted from the spectrum during nucleation time. In the higher mass range of Fig. 10a, ammonia-sulfuric acid peaks are clearly visible such as $\left(\mathrm{H}_{2} \mathrm{SO}_{4}\right)_{3} \mathrm{NH}_{3} \mathrm{HSO}_{4}^{-}$ $\left(m / z\right.$ 407.8888), $\quad\left(\mathrm{H}_{2} \mathrm{SO}_{4}\right)_{4}\left(\mathrm{NH}_{3}\right) \mathrm{HSO}_{4}^{-}(\mathrm{m} / z$ 505.8562), $\left(\mathrm{H}_{2} \mathrm{SO}_{4}\right)_{4}\left(\mathrm{NH}_{3}\right)_{2} \mathrm{HSO}_{4}^{-}\left(m / z\right.$ 522.8827), $\left(\mathrm{H}_{2} \mathrm{SO}_{4}\right)_{5}\left(\mathrm{NH}_{3}\right)_{2}$ $\mathrm{HSO}_{4}^{-} \quad(\mathrm{m} / \mathrm{z} 620.8501), \quad\left(\mathrm{H}_{2} \mathrm{SO}_{4}\right)_{5}\left(\mathrm{NH}_{3}\right)_{3} \mathrm{HSO}_{4}^{-} \quad(\mathrm{m} / \mathrm{z}$ 637.8767), $\left(\mathrm{H}_{2} \mathrm{SO}_{4}\right)_{6}\left(\mathrm{NH}_{3}\right)_{2} \mathrm{HSO}_{4}^{-} \quad(m / z 718.8175)$, $\left(\mathrm{H}_{2} \mathrm{SO}_{4}\right)_{6}\left(\mathrm{NH}_{3}\right)_{3} \mathrm{HSO}_{4}^{-}\left(\mathrm{m} / z\right.$ 735.8440), and $\left(\mathrm{H}_{2} \mathrm{SO}_{4}\right)_{6}$ $\left(\mathrm{NH}_{3}\right)_{4} \mathrm{HSO}_{4}^{-} \quad(m / z 752.8706)$. However, HOMs at high $m / z$ are also present, suggesting that these contribute to new particle formation in these events as well. In Fig. 10b, sulfuric acid-ammonia clusters are clearly absent. In contrast, elevated signals of compounds/clusters above $m / z \sim 300$ are observed, indicating that cluster formation of HOMs is driving new particle formation. Although some other organics are also observed to increase at lower masses, we consider it unlikely that these molecules contribute to the formation of new particles due to their relatively high saturation vapor pressure (Tröstl et al., 2016b). Most likely these molecules are formed concurrently with the HOMs and contribute to the growth of the freshly formed particles. Also, we cannot exclude participation of stabilizing ammonia in the cluster growth of the neutral clusters since this would not be detected in the anions.

The JFJ data are in excellent agreement with laboratory data reported from the CLOUD experiment where sulfuric acid-ammonia clusters were observed to grow by the progressive addition of $\mathrm{H}_{2} \mathrm{SO}_{4}$ and $\mathrm{NH}_{3}$ (Almeida et al., 2013; Kirkby et al., 2011; Schobesberger et al., 2015). Figure 11 demonstrates with a mass defect plot how closely the measurements at the Jungfraujoch (Fig. 11a) and the CLOUD chamber (Fig. 11b) resemble each other. In both cases, pure sulfuric acid clusters are dominant and the strongest signal was detected for the trimer $\left(\mathrm{H}_{2} \mathrm{SO}_{4}\right)_{2} \mathrm{HSO}_{4}^{-}$. Although clusters of the type $\left(\mathrm{H}_{2} \mathrm{SO}_{4}\right)_{m}\left(\mathrm{NH}_{3}\right)_{n} \mathrm{SO}_{5}^{-}$were measured in the CLOUD chamber, we did not observe them at the JFJ. A possible explanation could be the difference in RH. Kurtén et al. (2009) reported that under atmospheric conditions the hydration of $\mathrm{HSO}_{5}$ increases its lifetime significantly enhancing the probability to act as nucleation precursor. During the event shown in Fig. 11 the average RH at the JFJ was only $3 \%$ (temperature of $1.1{ }^{\circ} \mathrm{C}$ ) in comparison with $40 \% \mathrm{RH}$ in the CLOUD chamber (temperature of $5^{\circ} \mathrm{C}$ ). In the JFJ mass defect plot clusters involving amines (yellow dots) and iodate (cyan dots) are also present, but the dominant clusters have the composition $\left(\mathrm{H}_{2} \mathrm{SO}_{4}\right)_{m}\left(\mathrm{NH}_{3}\right)_{n} \cdot \mathrm{HSO}_{4}^{-}$as in the CLOUD spectrum. Concentrations of amines must be quite low as they are strong bases and are expected to bind strongly 


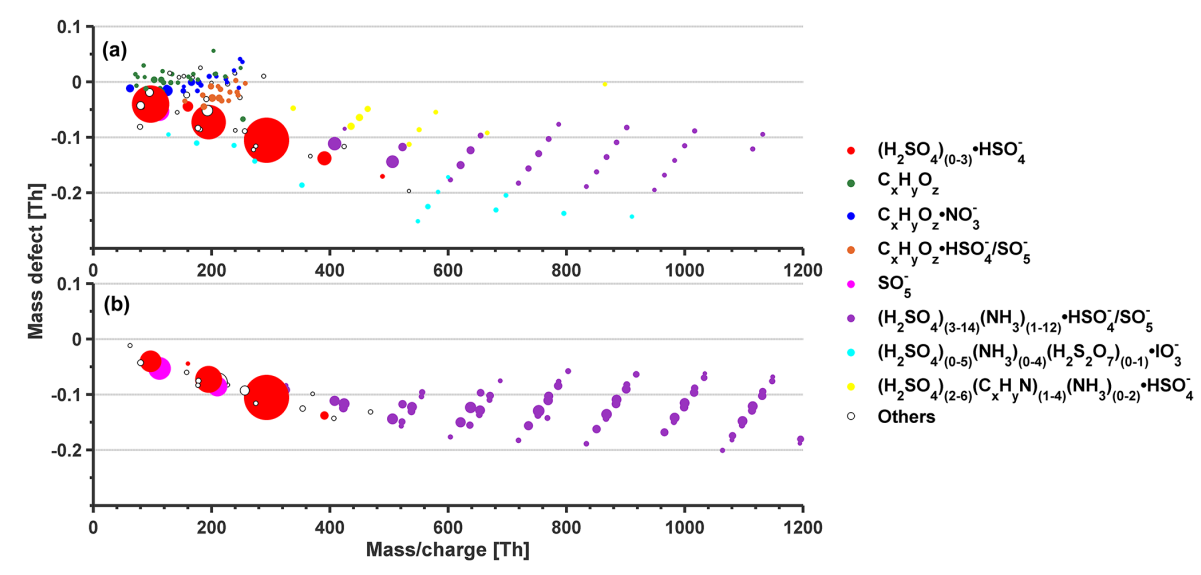

Figure 11. Comparison of ambient and laboratory measurements. (a) Mass defect plot from the Jungfraujoch on 12 November 2013 from 08:30 to 12:30 LST. (b) Mass defect plot from a laboratory experiment at the CLOUD chamber involving $\mathrm{H}_{2} \mathrm{SO}_{4}$ and $\mathrm{NH}_{3}$ clusters (adapted from Schobesberger et al., 2013).

to acids in the preexisting aerosol. Indeed, aminium compounds were found in the Jungfraujoch aerosol (Henning et al., 2003).

The LPDM FLEXPART (see Sect. 2.3) was used in timeinverse mode to detect the origin of the air masses transported during all the NPF events in order to determine the SRR. In addition, $\mathrm{CO}$ emissions were used as a tracer for emissions from anthropogenic activities, contained in air vented from the PBL. The back trajectories of all NPF events were compared to those of non-event days. We found that all NPF events (i.e., both the $\mathrm{H}_{2} \mathrm{SO}_{4}-\mathrm{NH}_{3}$ and $\mathrm{HOMs}$ types), were related to an increase in CO concentration and SRR 12 to $40 \mathrm{~h}$ before the arrival of the air mass at the JFJ, suggesting a PBL contact of the air mass within that time period (see also Bianchi et al., 2016). For all back trajectories, only a small increase in $\mathrm{CO}$ was found within $6 \mathrm{~h}$ before arrival at the JFJ, suggesting no significant influence from local emissions during this period. Thus, in a restricted time frame of 1-2 days after PBL contact, precursor gases are transported to the Jungfraujoch and may trigger NPF if oxidation of these gases leads to sufficiently high concentration of HOMs and/or sulfuric acid.

\section{Conclusions}

We conducted continuous measurements of atmospheric ions for 9 months at the high altitude research station Jungfraujoch (3454 m a.s.1.). The positive spectrum was composed mainly of cations of amines, predominantly pyridine, aniline, and benzylamine, as well as of organic molecules which showed a regular pattern with increasing $\mathrm{CH}_{2}$ moieties in the mass spectra. No strong diurnal behavior was observed, which is in agreement with observations by Ehn et al. (2010). The anion spectrum was usually dominated by sulfuric acid and its clusters, as well as nitric acid, $\mathrm{SO}_{5}^{-}$, and $\mathrm{CH}_{3} \mathrm{SO}_{3}^{-}$.
The latter two were most abundant during nighttime. Likewise, small organic molecules were detected frequently but no clear dependence on meteorological conditions nor diurnal cycle was found to be associated with their occurrence. During the total sampling period malonic acid was the most important organic compound besides MSA. Sulfuric acid was frequently detected also during nighttime and in some cases the signal was so high that even the tetramer was detected. The most likely explanation is that the measured sulfuric acid resulted from evaporation from the particle phase in the atmosphere under low RH conditions or in the instrument during events with high RH and snowfall.

We found a remarkably high correlation between $\mathrm{CH}_{3} \mathrm{SO}_{3}^{-}$ and $\mathrm{SO}_{5}^{-}\left(R^{2}=0.87\right)$ for the full measurement period. This correlation was not sensitive to boundary layer influences, as we observed high correlations at free-tropospheric and boundary-layer-influenced conditions. This correlation points to a common precursor for these two molecules. Considering DMS as common source would imply that all $\mathrm{SO}_{2}$ in the JFJ is derived from DMS excluding anthropogenic sources in contradiction with several studies that show local and PBL influence at the JFJ. Moreover, the almost permanent occurrence of $\mathrm{SO}_{5}^{-}$and $\mathrm{CH}_{3} \mathrm{SO}_{3}^{-}$during nighttime contradicts the typical photochemical production of MSA. Therefore, we conclude that an additional channel for MSA and $\mathrm{SO}_{5}^{-}$(probably $\mathrm{HSO}_{5}$ ) formation should be considered.

We frequently measured halogenated species with occasional events of high signals when more species could be detected. Backward transport simulations linked these events mainly with the Atlantic Ocean as source region although also continental influence was observed. Besides $\mathrm{IO}_{3}^{-}$we also measured $\mathrm{I}_{2} \mathrm{O}_{5}$, a species not reported so far in the atmosphere. Their signals as well as that of $\mathrm{Br}^{-}$rapidly decay when the sun rises and stay low during sunny days, without any other halogenated ions appearing instead. The 
mechanism of their formation and diurnal variation of these ions is unclear. Parallel measurements of neutral halogenated species need to be performed to elucidate their precursors.

Two types of new particle formation events were identified at the JFJ, one through sulfuric acid-ammonia cluster formation and a more frequent one via HOMs which were normally clustered with nitrate and only occasionally with sulfuric acid. The sulfuric acid-ammonia cluster formation during these nucleation events at the JFJ compared very well with laboratory experiments at the CLOUD chamber at CERN, confirming the relevance of this mechanism for ambient nucleation. New particle formation of HOMs was evidenced by an enhancement of ions above $m / z=300 \mathrm{Th}$. Such new particle formation that is primarily based on HOMs without significant participation of sulfuric acid was very recently found in the CLOUD experiment (Kirkby et al., 2016) and confirmed at the JFJ (Bianchi et al., 2016). New particle formation events take place at the JFJ 1-2 days after previous air mass contact with the PBL. This time frame appears to be needed to oxidize organic compounds transported towards the JFJ and trigger a HOM-based NPF.

\section{Data availability}

Data related to this article is available online at: https://doi. org/10.5281/zenodo.250401.

\section{The Supplement related to this article is available online at doi:10.5194/acp-17-2613-2017-supplement.}

Acknowledgements. We thank the International Foundation High Altitude Research Stations Jungfraujoch and Gornergrat for the opportunity to perform experiments on the Jungfraujoch and especially the research station's custodians Joan and Martin Fischer and Maria and Urs Otz for their support and hospitality. This work was supported by the Swiss National Science Foundation (200020_135307, 20020_152907, 206021_144947, 200021_140663), by MeteoSwiss in the framework of the Global Atmosphere Watch program and FP7 project ACTRIS (grant agreement no. 262254). Funding was also received from the Academy of Finland Centre of Excellence (grant no. 272041, 1118615), the EC Seventh Framework Program (Marie Curie Initial Training Network MC-ITN "CLOUD-TRAIN" no. 316662), the FP7 project BACCHUS (grant agreement no. 603445), and the ERC (under grant 615922-BLACARAT). We thank the tofTools team for providing tools for mass spectrometry analysis.

Edited by: A. Laskin

Reviewed by: three anonymous referees

\section{References}

Almeida, J., Schobesberger, S., Kürten, A., Ortega, I. K., Kupiainen-Määttä, O., Praplan, A. P., Adamov, A., Amorim, A., Bianchi, F., Breitenlechner, M., David, A., Dommen, J., Donahue, N. M., Downard, A., Dunne, E., Duplissy, J., Ehrhart, S., Flagan, R. C., Franchin, A., Guida, R., Hakala, J., Hansel, A., Heinritzi, M., Henschel, H., Jokinen, T., Junninen, H., Kajos, M., Kangasluoma, J., Keskinen, H., Kupc, A., Kurtén, T., Kvashin, A. N., Laaksonen, A., Lehtipalo, K., Leiminger, M., Leppä, J., Loukonen, V., Makhmutov, V., Mathot, S., McGrath, M. J., Nieminen, T., Olenius, T., Onnela, A., Petäjä, T., Riccobono, F., Riipinen, I., Rissanen, M., Rondo, L., Ruuskanen, T., Santos, F. D., Sarnela, N., Schallhart, S., Schnitzhofer, R., Seinfeld, J. H., Simon, M., Sipilä, M., Stozhkov, Y., Stratmann, F., Tomé, A., Tröstl, J., Tsagkogeorgas, G., Vaattovaara, P., Viisanen, Y., Virtanen, A., Vrtala, A., Wagner, P. E., Weingartner, E., Wex, H., Williamson, C., Wimmer, D., Ye, P., Yli-Juuti, T., Carslaw, K. S., Kulmala, M., Curtius, J., Baltensperger, U., Worsnop, D. R., Vehkamäki, H., and Kirkby, J.: Molecular understanding of sulphuric acid-amine particle nucleation in the atmosphere, Nature, 502, 359-363, doi:10.1038/nature12663, 2013.

Arnold, F.: Atmospheric ions and aerosol formation, Space Sci. Rev., 137, 225-239, doi:10.1007/s11214-008-9390-8, 2008.

Bardouki, H., Berresheim, H., Vrekoussis, M., Sciare, J., Kouvarakis, G., Oikonomou, K., Schneider, J., and Mihalopoulos, $\mathrm{N}$.: Gaseous (DMS, MSA, $\mathrm{SO}_{2}, \mathrm{H}_{2} \mathrm{SO}_{4}$ and DMSO) and particulate (sulfate and methanesulfonate) sulfur species over the northeastern coast of Crete, Atmos. Chem. Phys., 3, 1871-1886, doi:10.5194/acp-3-1871-2003, 2003.

Berresheim, H., Elste, T., Tremmel, H. G., Allen, A. G., Hansson, H.-C., Rosman, K., Maso, M. D., Makela, J. M., Kulmala, M., and O'Downd, C. D.: Gas-aerosol relationships of $\mathrm{H}_{2} \mathrm{SO}_{4}$, MSA, and $\mathrm{OH}$ : Observations in the coastal marine boundary layer at Mace Head, Ireland, J. Geophys. Res., 107, 8100, doi:10.1029/2000JD000229, 2002.

Berresheim, H., Adam, M., Monahan, C., O’Dowd, C., Plane, J. M. C., Bohn, B., and Rohrer, F.: Missing $\mathrm{SO}_{2}$ oxidant in the coastal atmosphere - observations from high-resolution measurements of $\mathrm{OH}$ and atmospheric sulfur compounds, Atmos. Chem. Phys., 14, 12209-12223, doi:10.5194/acp-14-12209-2014, 2014.

Bianchi, F., Tröstl, J., Junninen, H., Frege, C., Henne, S., Hoyle, C. R., Molteni, U., Herrmann, E., Adamov, A., Bukowiecki, N., Chen, X., Duplissy, J., Gysel, M., Hutterli, M., Kangasluoma, J., Kontkanen, J., Kürten, A., Manninen, H. E., Münch, S., Peräkylä, O., Petäjä, T., Rondo, L., Williamson, C., Weingartner, E., Curtius, J., Worsnop, D. R., Kulmala, M., Dommen, J., and Baltensperger, U.: New particle formation in the free troposphere: A question of chemistry and timing, Science, 352, 1109-1112, doi:10.1126/science.aad5456, 2016.

Bork, N., Kurtén, T., and Vehkamäki, H.: Exploring the atmospheric chemistry of $\mathrm{O}_{2} \mathrm{SO}_{3}^{-}$and assessing the maximum turnover number of ion-catalysed $\mathrm{H}_{2} \mathrm{SO}_{4}$ formation, Atmos. Chem. Phys., 13, 3695-3703, doi:10.5194/acp-13-3695-2013, 2013.

Boulon, J., Sellegri, K., Venzac, H., Picard, D., Weingartner, E., Wehrle, G., Collaud Coen, M., Bütikofer, R., Flückiger, E., Baltensperger, U., and Laj, P.: New particle formation and ultrafine charged aerosol climatology at a high altitude site in the Alps (Jungfraujoch, $3580 \mathrm{~m}$ a.s.l., Switzerland), Atmos. Chem. Phys., 10, 9333-9349, doi:10.5194/acp-10-9333-2010, 2010. 
Bukowiecki, N., Weingartner, E., Gysel, M., Collaud Coen, M., Zieger, P., Herrmann, E., Steinbacher, M., Gäggeler, H. W., and Baltensperger, U.: A review of more than 20 years of aerosol observation at the High Altitude Research Station Jungfraujoch, Switzerland (3580 m asl), Aerosol Air Qual. Res., 16, 764-788, doi:10.4209/aaqr.2015.05.0305, 2016.

Ehn, M., Junninen, H., Petäjä, T., Kurtén, T., Kerminen, V.-M., Schobesberger, S., Manninen, H. E., Ortega, I. K., Vehkamäki, H., Kulmala, M., and Worsnop, D. R.: Composition and temporal behavior of ambient ions in the boreal forest, Atmos. Chem. Phys., 10, 8513-8530, doi:10.5194/acp-10-8513-2010, 2010.

Fröhlich, R., Cubison, M. J., Slowik, J. G., Bukowiecki, N., Canonaco, F., Croteau, P. L., Gysel, M., Henne, S., Herrmann, E., Jayne, J. T., Steinbacher, M., Worsnop, D. R., Baltensperger, U., and Prévôt, A. S. H.: Fourteen months of on-line measurements of the non-refractory submicron aerosol at the Jungfraujoch (3580 ma.s.1.) - Chemical composition, origins and organic aerosol sources, Atmos. Chem. Phys., 15, 11373-11398, doi:10.5194/acp-15-11373-2015, 2015.

Gleason, J. F., Sinha, A., and Howard, C. J.: Kinetics of the Gasphase reaction $\mathrm{HOSO}_{2}+\mathrm{O}_{2}->\mathrm{HO}_{2}+\mathrm{SO}_{3}$, J. Phys. Chem., 91, 719-724, 1987.

Heitmann, H. and Arnold, F.: Composition measurements of tropospheric ions, Nature, 306, 747-751, doi:10.1038/306747a0, 1983.

Henne, S., Brunner, D., Folini, D., Solberg, S., Klausen, J., and Buchmann, B.: Assessment of parameters describing representativeness of air quality in-situ measurement sites, Atmos. Chem. Phys., 10, 3561-3581, doi:10.5194/acp-10-3561-2010, 2010.

Henning, S., Weingartner, E., Schwikowski, M., Gäggeler, H. W., Gehrig, R., Hinz, K.-P., Trimborn, A., Spengler, B., and Baltensperger, U.: Seasonal variation of water-soluble ions of the aerosol at the high-alpine site Jungfraujoch ( $3580 \mathrm{~m}$ asl), J. Geophys. Res., 108, 4030, doi:10.1029/2002JD002439, 2003.

Herrmann, E., Weingartner, E., Henne, S., Vuilleumier, L., Bukowiecki, N., Steinbacher, M., Conen, F., Collaud Coen, M., Hammer, E., Juranyi, Z., Baltensperger, U., and Gysel, M.: Analysis of long-term aerosol size distribution data from Jungfraujoch with emphasis on free tropospheric conditions, cloud influence, and air mass transport, J. Geophys. Res.-Atmos., 120, 9459-9480, doi:10.1002/2015JD023660, 2015.

Hirsikko, A., Nieminen, T., Gagné, S., Lehtipalo, K., Manninen, H. E., Ehn, M., Hõrrak, U., Kerminen, V.-M., Laakso, L., McMurry, P. H., Mirme, A., Mirme, S., Petäjä, T., Tammet, H., Vakkari, V., Vana, M., and Kulmala, M.: Atmospheric ions and nucleation: a review of observations, Atmos. Chem. Phys., 11, 767798, doi:10.5194/acp-11-767-2011, 2011.

Junninen, H., Ehn, M., Petäjä, T., Luosujärvi, L., Kotiaho, T., Kostiainen, R., Rohner, U., Gonin, M., Fuhrer, K., Kulmala, M., and Worsnop, D. R.: A high-resolution mass spectrometer to measure atmospheric ion composition, Atmos. Meas. Tech., 3, 10391053, doi:10.5194/amt-3-1039-2010, 2010.

Kaltsoyannis, N. and Plane, J. M. C.: Quantum chemical calculations on a selection of iodine-containing species (IO, $\mathrm{OIO}, \mathrm{INO}_{3},(\mathrm{IO})_{2}, \mathrm{I}_{2} \mathrm{O}_{3}, \mathrm{I}_{2} \mathrm{O}_{4}$ and $\mathrm{I}_{2} \mathrm{O}_{5}$ ) of importance in the atmosphere, Phys. Chem. Chem. Phys., 10, 1723-1733, doi:10.1039/b715687c, 2008.

Kirkby, J.: Cosmic rays and climate, Surv. Geophys., 28, 333-375, doi:10.1007/s10712-008-9030-6, 2007.
Kirkby, J., Curtius, J., Almeida, J., Dunne, E., Duplissy, J., Ehrhart, S., Franchin, A., Gagné, S., Ickes, L., Kürten, A., Kupc, A., Metzger, A., Riccobono, F., Rondo, L., Schobesberger, S., Tsagkogeorgas, G., Wimmer, D., Amorim, A., Bianchi, F., Breitenlechner, M., David, A., Dommen, J., Downard, A., Ehn, M., Flagan, R. C., Haider, S., Hansel, A., Hauser, D., Jud, W., Junninen, H., Kreissl, F., Kvashin, A., Laaksonen, A., Lehtipalo, K., Lima, J., Lovejoy, E. R., Makhmutov, V., Mathot, S., Mikkilä, J., Minginette, P., Mogo, S., Nieminen, T., Onnela, A., Pereira, P., Petäjä, T., Schnitzhofer, R., Seinfeld, J. H., Sipilä, M., Stozhkov, Y., Stratmann, F., Tomé, A., Vanhanen, J., Viisanen, Y., Vrtala, A., Wagner, P. E., Walther, H., Weingartner, E., Wex, H., Winkler, P. M., Carslaw, K. S., Worsnop, D. R., Baltensperger, U., and Kulmala, M.: Role of sulphuric acid, ammonia and galactic cosmic rays in atmospheric aerosol nucleation, Nature, 476, 429-433, doi:10.1038/nature10343, 2011.

Kirkby, J., Duplissy, J., Sengupta, K., Frege, C., Gordon, H., Williamson, C., Heinritzi, M., Simon, M., Yan, C., Almeida, J., Tröstl, J., Nieminen, T., Ortega, I. K., Wagner, R., Adamov, A., Amorim, A., Bernhammer, A.-K., Bianchi, F., Breitenlechner, M., Brilke, S., Chen, X., Craven, J., Dias, A., Ehrhart, S., Flagan, R. C., Franchin, A., Fuchs, C., Guida, R., Hakala, J., Hoyle, C. R., Jokinen, T., Junninen, H., Kangasluoma, J., Kim, J., Krapf, M., Kürten, A., Laaksonen, A., Lehtipalo, K., Makhmutov, V., Mathot, S., Molteni, U., Onnela, A., Peräkylä, O., Piel, F., Petäjä, T., Praplan, A. P., Pringle, K., Rap, A., Richards, N. A. D., Riipinen, I., Rissanen, M. P., Rondo, L., Sarnela, N., Schobesberger, S., Scott, C. E., Seinfeld, J. H., Sipilä, M., Steiner, G., Stozhkov, Y., Stratmann, F., Tomé, A., Virtanen, A., Vogel, A. L., Wagner, A. C., Wagner, P. E., Weingartner, E., Wimmer, D., Winkler, P. M., Ye, P., Zhang, X., Hansel, A., Dommen, J., Donahue, N. M., Worsnop, D. R., Baltensperger, U., Kulmala, M., Carslaw, K. S., and Curtius, J.: Ion-induced nucleation of pure biogenic particles, Nature, 533, 521-526, doi:10.1038/nature17953, 2016.

Kurtén, T., Berndt, T., and Stratmann, F.: Hydration increases the lifetime of $\mathrm{HSO}_{5}$ and enhances its ability to act as a nucleation precursor - a computational study, Atmos. Chem. Phys., 9, 33573369, doi:10.5194/acp-9-3357-2009, 2009.

Marty, C. and Philipona, R.: The clear-sky index to separate clearsky from cloudy-sky situations in climate research, Geophys. Res. Lett., 27, 2649-2652, doi:10.1029/2000GL011743, 2000.

Mauldin, R. L., Mauldin R. L., I. I. I., Cantrell, C. A., Zondlo, M., Kosciuch, E., Eisele, F. L., Chen, G., Davis, D., Weber, R., Crawford, J., Blake, D., Bandy, A., and Thornton, D.: Highlights of $\mathrm{OH}, \mathrm{H}_{2} \mathrm{SO}_{4}$, and methane sulfonic acid measurements made aboard the NASA P-3B during transport and chemical evolution over the Pacific, J. Geophys. Res., 108, 8796, doi:10.1029/2003JD003410, 2003.

Mauldin III, R. L., Tanner, D. J., Heath, J. A., Huebert, B. J., and Eisele, F. L.: Observations of $\mathrm{H}_{2} \mathrm{SO}_{4}$ and MSA during PEM-Tropics-A, J. Geophys. Res., 104, 5801-5816, doi:10.1029/98JD02612, 1999.

Mauldin III, R. L., Berndt, T., Sipilä, M., Paasonen, P., Petäjä, T., Kim, S., Kurtén, T., Stratmann, F., Kerminen, V.-M., and Kulmala, M.: A new atmospherically relevant oxidant of sulphur dioxide, Nature, 488, 193-196, doi:10.1038/nature11278, 2012.

Möhler, O., Reiner, T., and Arnold, F.: The formation of $\mathrm{SO}_{5}^{-}$by gas phase ion-molecule reactions, J. Chem. Phys., 97, 8233, doi:10.1063/1.463394, 1992. 
O’Dowd, C. D., Jimenez, J. L., Bahreini, R., Flagan, R. C., Seinfeld, J. H., Hämeri, K., Pirjola, L., Kulmala, M., Jennings, G. S., and Hoffmann, T.: Marine aerosol formation from biogenic iodine emissions, Nature, 417, 1-5, doi:10.1038/nature00775, 2002.

Rose, C., Sellegri, K., Velarde, F., Moreno, I., Ramonet, M., Weinhold, K., Krejci, R., Ginot, P., Andrade, M., Wiedensohler, A., and Laj, P.: Frequent nucleation events at the high altitude station of Chacaltaya (5240 m a.s.1.), Bolivia, Atmos. Environ., 102, 18-29, doi:10.1016/j.atmosenv.2014.11.015, 2015.

Salcedo, D., Villalta, P. W., Varutbangkul, V., Wormhoudt, J. C., Miake-Lye, R. C., Worsnop, D. R., Ballenthin, J. O., Thorn, W. F., Viggiano, A. A., Miller, T. M., Flagan, R. C., and Seinfeld, J. H.: Effect of relative humidity on the detection of sulfur dioxide and sulfuric acid using a chemical ionization mass spectrometer, Int. J. Mass Spectrom., 231, 17-30, doi:10.1016/j.ijms.2003.09.005, 2004.

Saunders, R. W. and Plane, J. M. C.: Formation pathways and composition of iodine oxide ultra-fine particles, Environ. Chem., 2, 299-303, doi:10.1071/EN05079, 2005.

Schobesberger, S., Junninen, H., Bianchi, F., Lönn, G., Ehn, M., Lehtipalo, K., Dommen, J., Ehrhart, S., Ortega, I. K., Franchin, A., Nieminen, T., Riccobono, F., Hutterli, M., Duplissy, J., Almeida, J., Amorim, A., Breitenlechner, M., Downard, A. J., Dunne, E. M., Flagan, R. C., Kajos, M., Keskinen, H., Kirkby, J., Kupc, A., Kürten, A., Kurtén, T., Laaksonen, A., Mathot, S., Onnela, A., Praplan, A. P., Rondo, L., Santos, F. D., Schallhart, S., Schnitzhofer, R., Sipilä, M., Tomé, A., Tsagkogeorgas, G., Vehkamäki, H., Wimmer, D., Baltensperger, U., Carslaw, K. S., Curtius, J., Hansel, A., Petäjä, T., Kulmala, M., Donahue, N. M., and Worsnop, D. R.: Molecular understanding of atmospheric particle formation from sulfuric acid and large oxidized organic molecules, P. Natl. Acad. Sci. USA, 110, 17223-17228, doi:10.1073/pnas.1306973110, 2013.

Schobesberger, S., Franchin, A., Bianchi, F., Rondo, L., Duplissy, J., Kürten, A., Ortega, I. K., Metzger, A., Schnitzhofer, R., Almeida, J., Amorim, A., Dommen, J., Dunne, E. M., Ehn, M., Gagné, S., Ickes, L., Junninen, H., Hansel, A., Kerminen, V.-M., Kirkby, J., Kupc, A., Laaksonen, A., Lehtipalo, K., Mathot, S., Onnela, A., Petäjä, T., Riccobono, F., Santos, F. D., Sipilä, M., Tomé, A., Tsagkogeorgas, G., Viisanen, Y., Wagner, P. E., Wimmer, D., Curtius, J., Donahue, N. M., Baltensperger, U., Kulmala, M., and Worsnop, D. R.: On the composition of ammonia-sulfuric-acid ion clusters during aerosol particle formation, Atmos. Chem. Phys., 15, 55-78, doi:10.5194/acp-15-55-2015, 2015.

Schulte, P. and Arnold, F.: Pyridinium ions and pyridine in the free troposphere, Geophys. Res. Lett., 17, 1077-1080, doi:10.1029/GL017i008p01077, 1990.

Seinfeld, J. H. and Pandis, S. N.: Atmospheric chemistry and physics. From air pollution to climate change, 2nd Edn., John Wiley \& Sons, Inc., Hoboken, New Jersey, 2006.

Simpson, W. R., Brown, S. S., Saiz-Lopez, A., Thornton, J. A., and von Glasow, R.: Tropospheric halogen chemistry: sources, cycling, and impacts, Chem. Rev., 15, 4035-4062, doi:10.1021/cr5006638, 2015.

Smith, D. and Spanel, P.: Ions in the terrestrial atmosphere and in the interstellar clouds, Mass Spectrom. Rev., 14, 255-278, doi:10.1002/mas.1280140403, 1996.
Stockwell, W. R. and Calvert, J. G.: The mechanism of the $\mathrm{HO}-\mathrm{SO}_{2}$ reaction, Atmos. Environ., 17, 2231-2235, doi:10.1016/00046981(83)90220-2, 1983.

Stohl, A., Spichtinger-Rakowsky, N., Bonasoni, P., Feldmann, H., Memmesheimer, M., Scheel, H. E., Trickl, T., Hübener, S., Ringer, W., and Mandl, M.: The influence of stratospheric intrusions on alpine ozone concentrations, Atmos. Environ., 34, 1323-1354, doi:10.1016/S1352-2310(99)00320-9, 2000.

Stohl, A., Forster, C., Frank, A., Seibert, P., and Wotawa, G.: and Physics Technical note: The Lagrangian particle dispersion model FLEXPART version 6.2, Atmos. Chem. Phys., 5, 24612474, doi:10.5194/acp-5-2461-2005, 2005.

Tröstl, J., Herrmann, E., Frege, C., Bianchi, F., Molteni, U., Bukowiecki, N., Hoyle, C. R., Steinbacher, M., Weingartner, E., Dommen, J., Gysel, M., and Baltensperger, U.: Contribution of new particle formation to the total aerosol concentration at the high-altitude site Jungfraujoch $(3580 \mathrm{~m}$ asl, Switzerland), J. Geophys. Res.-Atmos., 121, 11692-11711, doi:10.1002/2015JD024637, 2016a.

Tröstl, J., Chuang, W. K., Gordon, H., Heinritzi, M., Yan, C., Molteni, U., Ahlm, L., Frege, C., Bianchi, F., Wagner, R., Simon, M., Lehtipalo, K., Williamson, C., Craven, J. S., Duplissy, J., Adamov, A., Almeida, J., Bernhammer, A.-K., Breitenlechner, M., Brilke, S., Dias, A., Ehrhart, S., Flagan, R. C., Franchin, A., Fuchs, C., Guida, R., Gysel, M., Hansel, A., Hoyle, C. R., Jokinen, T., Junninen, H., Kangasluoma, J., Keskinen, H., Kim, J., Krapf, M., Kürten, A., Laaksonen, A., Lawler, M. J., Leiminger, M., Mathot, S., Möhler, O., Nieminen, T., Onnela, A., Petäjä, T., Piel, F., Miettinen, P., Rissanen, M. P., Rondo, L., Sarnela, N., Schobesberger, S., Sengupta, K., Sipilä, M., Smith, J. N., Steiner, G., Tomé, A., Virtanen, A., Wagner, A. C., Weingartner, E., Wimmer, D., Winkler, P. M., Ye, P., Carslaw, K. S., Curtius, J., Dommen, J., Kirkby, J., Kulmala, M., Riipinen, I., Worsnop, D. R., Donahue, N. M., and Baltensperger, U.: The role of low-volatility organic compounds for initial particle growth in the atmosphere, Nature, 533, 527-531, doi:10.1038/nature18271, 2016b.

Tsagkogeorgas, G., Roldin, P., Duplissy, J., Rondo, L., Tröstl, J., Slowik, J. G., Ehrhart, S., Franchin, A., Kürten, A., Amorim, A., Bianchi, F., Kirkby, J., Petäjä, T., Baltensperger, U., Boy, M., Curtius, J., Flagan, R. C., Kulmala, M., Donahue, N. M., and Stratmann, F.: Evaporation of sulphate aerosols at low relative humidity, Atmos. Chem. Phys. Discuss., doi:10.5194/acp-20161045, in review, 2016.

Venzac, H., Sellegri, K., Laj, P., Villani, P., Bonasoni, P., Marinoni, A., Cristofanelli, P., Calzolari, F., Fuzzi, S., Decesari, S., Facchini, M.-C., Vuillermoz, E., and Verza, G. Pietro: High frequency new particle formation in the Himalayas, P. Natl. Acad. Sci. USA, 105, 15666-15671, doi:10.1073/pnas.0801355105, 2008.

Zellweger, C., Forrer, J., Hofer, P., Nyeki, S., Schwarzenbach, B., Weingartner, E., and Ammann, M.: Partitioning of reactive nitrogen $\left(\mathrm{NO}_{y}\right)$ and dependence on meteorological conditions in the lower free troposphere, Atmos. Chem. Phys., 3, 779-796, doi:10.5194/acp-3-779-2003, 2003.

Zhao, J., Smith, J. N., Eisele, F. L., Chen, M., Kuang, C., and McMurry, P. H.: Observation of neutral sulfuric acid-amine containing clusters in laboratory and ambient measurements, Atmos. Chem. Phys., 11, 10823-10836, doi:10.5194/acp-1110823-2011, 2011. 